\title{
Antioxidants, their properties, uses in food products and their legal implications
}

\author{
Indrajit D. Thorata ${ }^{\mathrm{a}^{*}}$, Dipali D. Jagtap ${ }^{\mathrm{b}}$, Debabandya Mohapatra ${ }^{\mathrm{c}}$, D.C. Joshi ${ }^{\mathrm{b}}$, \\ R.F. SUTAR ${ }^{\mathrm{b}}$, AND S.S. KAPDI ${ }^{\mathrm{b}}$ \\ ${ }^{a}$ Global Center of Excellence for Design \& Application Development (GCEDAD), IDMC Ltd., GIDC, Anand, \\ India \\ ${ }^{\mathrm{b}}$ College of Food Processing Technology \& Bio-Energy, Anand Agricultural University, Anand, India \\ ${ }^{\mathrm{c}}$ Central Institute of Agricultural Engineering, Bhopal, India \\ * Corresponding author \\ idthorat@gmail.com \\ TEL: +91-9552542045
}

Received: 4 July 2012; Published online: 18 April 2013

\begin{abstract}
Oxidation decreases consumer acceptability of food by changing its organoleptic properties, destroying essential nutrients and producing toxic compounds. Antioxidants delay oxidation of lipids in foods as well in human systems. Studies reveal that synthetic antioxidants may trigger diseases in human when consumed over a certain concentration. The toxicological effects of synthetic food antioxidants have been the focus of controversy in recent years. There is scope to use natural antioxidants, present in many components of food and plant sources, as a preservative. In this review different synthetic and natural antioxidants present in various foods, reactions with food and the biological system, extraction techniques and their pitfalls as well as legal implication are discussed.
\end{abstract}

Keywords: synthetic antioxidant, natural antioxidants, lipid oxidation.

\section{Introduction}

Antioxidants are a group of substances which, when present at low concentrations, in relation to oxidizable substrates, significantly inhibit or delay oxidative processes, while often being oxidized themselves. The applications of antioxidants have been widespread in the food industry for decades; and are in use in preventing lipids from oxidative degradation (Vaya \& Aviram, 1999). Free radical reactions play an important role in oxidative degradation of lipids by the production of peroxides and their derivatives, which produce off-flavors in foods (Gordon, 2001). Antioxidants protect cells against the effects of harmful free radicals. There exists scientific evidence that the excessive production of free radicals in the organism, and the imbalance between their concentration and the antioxidant defences, may be related to processes such as aging (Calabrese \& Maines, 2006) and diseases such as cancer (Johnson, 2001; Mantovani et al., 2003), atherosclerosis (Siekmeier, Steffen, \& Maerz, 2007), stroke (Spence, 2006), rheumatoid arthritis (Firuzi et al., 2006), neurodegeneration (Droge \& Schipper, 2007), inflammatory disorders (Geronikaki \& Gavalas, 2006) and diabetes (Rahimi, Nikfar, Larijani, \& Abdollahi, 2005). Many studies have revealed that antioxidants may play an important role in preventing diseases caused by free radicals. With evolving health consciousness in the consumer, food for well-being and health is the new trend that has caught the attention of food processors and sci- 
entists equally. This has led to incorporation of antioxidants in foods from various sources. A report from market analysts revealed that consumer pressure and revised legislation is causing a shift in antioxidant trends. From the year 2000 to 2009 , the $€ 15$ million total European antioxidant market was estimated to grow by a mere 1.7 per cent; while a compound annual growth rate of $35 \%$ was foreseen for natural antioxidants (Ibbotson, 2008).

Lipid oxidation has long been recognized as a major problem in the storage of fatty foods. Oxidative changes can result in repugnant flavors, destruction of valuable nutrients and even generate toxic compounds leading to economic loss to the producer and consumer. Unsaturated fatty acids are the potential sources of oxidative offflavors in fatty products and significantly contribute to the shelf life of many products such as ghee (clarified butter), butter, fat spread, milk powders, etc. (Madhavi, 1995).

The term antioxidant originally was used to refer specifically to a chemical that prevents the consumption of oxygen. According to the Prevention of Food Adulteration (PFA) Act, antioxidant means "a substance which when added to food retards or prevents oxidative deterioration of food and does not include sugars, cereal oils, flours, herbs and spices" (PFA - Prevention of Food Adulteration, 2008). Early research on the role of antioxidants in biology focused on their use in preventing the oxidation of unsaturated fats. They function as free radical acceptors, thereby terminating the oxidation process at the initial step in autoxidation (Bodnar, 2010).

The major antioxidants currently used in foods are monohydroxy or polyhydroxy phenol compounds with various ring substitutions. These compounds have low activation energy to donate hydrogen. The resulting free radical does not initiate another free radical due to the stabilization of delocalized radical electron, and is not subject to rapid oxidation due to its stability; the free radicals can react with lipid free radicals to form stable complex compounds (Pokorny, 2001).

\section{Major Oxidative Changes In Food Products}

The storage of fat-containing food materials is limited by the period of slow oxidation, where the sensory value is still acceptable. The stage of very slow oxidation in the beginning of storage is called the induction period. The induction period, and thus the shelf life, may be prolonged by addition of antioxidants, which are not able to entirely eliminate the oxidation reactions even when they are active in prolonging the storage time. Several types of rancidity exist in fats, oils and fatty foods, not always connected with oxidation reactions. The most important types are listed in Table 1 (Pokorny, 2008). Fats, oils and related compounds, which turn rancid on oxidation, are mostly oxidized by oxygen in the air that penetrates foods and is dissolved in both aqueous and lipid phases. If the reaction is catalyzed by enzymes, the oxidant is still air oxygen. Other oxidants (Table 2) (Pokorny, 2008) are of minor importance. In the presence of photo-sensibilizers (such as chlorophylls) and in light, ordinary triplet oxygen is converted into singlet oxygen, which is 1500 times more reactive (Bradley \& Min, 1992).

Fats and oils are highly vulnerable to oxidation, which can be initiated by enzymatic and nonenzymatic mechanisms. Singlet oxygen can be generated by the photosensitization of molecular oxygen by lights which in turn initiate the lipid oxidation by reacting with unsaturated fatty acids of food products (Adegoke et al., 1998). Oxidation of $\beta$-carotene and vitamin A results in release of more polar oxidation products. The oxidative destruction of the fat soluble vitamins (A, D, E and K) has important nutritional implication. Some amino acids can also undergo oxidation along with the oxidizing lipids (Min, 2007). Food lipids are susceptible to the oxidation process, which takes place in different steps like initiation, propagation and termination (Brien \& Connor, 2003). Different chemical mechanisms are responsible for the oxidation of fats and oils during processing, storage and cooking. Some of these mechanisms are discussed briefly in the following section. 
Table 1: Types of rancidity occurring in fats, oils and fatty acids (Pokorny, 2008).

\begin{tabular}{cccc}
\hline $\begin{array}{c}\text { Types of } \\
\text { rancidity }\end{array}$ & $\begin{array}{c}\text { Main substances } \\
\text { producing rancidity }\end{array}$ & $\begin{array}{c}\text { Types of chemical } \\
\text { reaction }\end{array}$ & $\begin{array}{c}\text { Materials subject to } \\
\text { the type of rancidity }\end{array}$ \\
\hline Lipolytic & $\begin{array}{c}\text { Low fatty acids, medium chain } \\
\text { fatty acids }\end{array}$ & Enzymic hydrolysis & Milk fat, palm seed oils \\
Oxidative & Lower aldehydes and ketones & $\begin{array}{c}\text { Autoxidation, enzymic } \\
\text { oxidation }\end{array}$ & $\begin{array}{c}\text { Polyunsaturated edible } \\
\text { oil }\end{array}$ \\
Flavor reversion & $\begin{array}{c}\text { Oxygen substituted cleavage } \\
\text { and rearrangement products } \\
\text { 2-Alkanones (methyl ketones) }\end{array}$ & $\begin{array}{c}\text { Oxidation cleavage, and } \\
\text { rearrangement }\end{array}$ & Soxidation and enzymic \\
Ketonic & decarboxylation & Milk fat, palm seed oils \\
\hline
\end{tabular}

Table 2: Oxidants in food products (Pokorny, 2008).

\begin{tabular}{ccc}
\hline Oxidant & Importance & Occurrence \\
\hline $\begin{array}{c}\text { Air (triplet) oxygen } \\
\text { (autoxidation) } \\
\begin{array}{c}\text { Enzymatically catalyzed } \\
\text { oxidation }\end{array}\end{array}$ & $\begin{array}{c}\text { Most important in processed } \\
\text { and stored foods } \\
\text { Singlet oxygen }\end{array}$ & Stored raw materials \\
In light and in the presence & Oilseeds, nuts, cereals, legumes \\
Of photo sensitizer & Very low in foods & Edible oils, green foods \\
Quinines & In foods subject to enzymic & Fruit, vegetables, potatoes \\
Metals & browning & Essential oils \\
Superoxide anion & Initiation of free radical oxidation \\
Hydrogen peroxide & Mainly in vivo systems \\
Lipid hydroperoxides & In presence of ascorbic acid & Meat \\
& In presence of polyunsaturated & Fruits, vegetables, fatty foods \\
\hline
\end{tabular}

\subsection{Autoxidation}

Autoxidation is an autocatalytic complex chemical reaction in environment between unsaturated fatty acids or their esters and oxygen (molecular or singlet oxygen) mediated by a variety of catalysts. Autoxidation leads to the formation of several peroxide compounds, which are, relatively unstable non-volatile and odorless compounds, and their decomposition products (alcohols, aldehydes, ketones) impart oxidative offflavors in fat-rich food products (Gordon, 2001). The atmospheric triplet oxygen, having a radical character, reacts with radicals and causes autoxidation. The non-radical electrophilic singlet oxygen does not require radicals to react with; it directly reacts with the double bonds of unsaturated fats and oils with high electron densities, which is called type II photosensitized oxidation
(Choe \& Min, 2005).

Fat oxidation is influenced by a range of parameters, like exposure to light, temperature, presence of pro-oxidant metals, presence of antioxidant compounds and the degree of unsaturated fat (Fox \& McSweeney, 1998).

\section{$2.2 \quad$ Photo-oxidation}

Light accelerates lipid oxidation, especially in the presence of photosensitizers such as chlorophylls. Chlorophylls in singlet state become excited upon absorption of light energy in 1 pico second (Choe \& Min, 2006). 


\subsection{Thermal oxidation}

Heating of oil produces various chemical changes including oxidation. The chemical mechanism of thermal oxidation is basically the same as the autoxidation mechanism. The rate of thermal oxidation is faster than the autoxidation, and the unstable primary oxidation products, hydroperoxides, are decomposed rapidly into secondary oxidation products such as aldehydes and ketones (Choe \& Min, 2007).

\subsection{Enzymatic oxidation}

The oxidation of lipids can also be catalyzed enzymatically. Lipoxygenase is an iron-bound enzyme with $\mathrm{Fe}$ in its active center. Lipoxygenase oxidizes unsaturated fatty acids having a 1-cis, 4-cis-pentadiene system, resulting in oil deterioration, and oils containing linoleic, linolenic, and arachidonic acids are favored substrates (Hsieh \& Kinsella, 1986). Eicosapentaenoic acid (EPA) and docosahexaenoic acid (DHA) can also be oxidized by lipoxygenase (Wang, Miller, \& Addis, 1991).

\section{Classification of Antioxidants}

Antioxidants are naturally present in a wide variety of raw materials, but can also be added to foods for additional protection against oxidation. The antioxidants which are added to food products can be natural or synthetic compounds depending on their availability, and preparations (Yanishlieva-Maslarova, 2001).

\subsection{Natural antioxidants}

The beneficial effects of foods are being partially attributed to naturally occurring antioxidant substances (Vision et al., 1999). The search for natural sources of compounds with functional activity to be added to foods (functional) for specific population groups (diabetics, hypertensive, etc.) is important and necessary. It is generally accepted, that natural antioxidant molecules are safer than synthetic antioxidants, available in complex forms, which include tocopherols, lycopenes, flavonoids, nordihydroguaretic acid
(NDGA), sesamol, gossypol, vitamins, provitamins and other phytochemicals, enzymes (catalase, glutathione peroxidase, super oxide dismutase), minerals (Zinc, Selenium), and lecithin (Cuppett, 2001). Alpha( $\alpha$ )-tocopherol (vitamin $\mathrm{E})$ is well known as one of the most efficient naturally occurring lipid-soluble antioxidants (McCarthy, Kerry, Kerry, Lynch, \& Buckley, 2001). In recent years, due to increasing public awareness regarding health and wellbeing and apprehension of using synthetic antioxidants in food system, there has been a growing interest to identify and utilize antioxidative properties in many natural sources such as soy protein (Moure, Dominguez, \& Parajo, 2006), alfalfa leaf protein (Xie, Huang, Xu, \& Jin, 2008), chickpea protein (Li, Han, \& Chen, 2008a; Li, Jiang, Zhang, Mu, \& Liu, 2008b), wheat germ protein (Zhu, Zhou, \& Qian, 2006), gluten (Castillo et al., 2007), rice bran (Jayadeep, Singh, Rao, Srinivas, \& Ali, 2009), canola (Cumby, Zhong, Naczk, \& Shahidi, 2008), corn (Li et al., 2008a; Li et al., 2008b), muscle protein (Ali et al., 2009), dill leaf (Rekha, Yadav, Dharmesh, Chauhan, \& Ramteke, 2010), Mexican oregano (Avila-Sosa, Guadalupe GastelumFranco, Camacho-Davila, Vinicio Torres-Munoz, \& Virginia Nevarez-Moorillon, 2010), elderberry (Seabra, Braga, Batista, \& de Sousa, 2010), and sweet basil (Leal et al., 2008). Pan, Jiang, and Pan (2011) found rapeseed protein hydrolysates to be a potential source of antioxidants in addition to high quality protein for human consumption.

The antioxidant compounds in selected fruits or berry and vegetables and their products are listed in Tables 3 and 4 (Heinonen, Ollilainen, Linkola, Varo, \& Koivistoinen, 1989; Plumb, Chambers, Lambert, Wanigatunga, \& Williamson, 1997; Hollman \& Arts, 2000; Hussein et al., 2000; van den Berg et al., 2000; Matilla, Suanpa, \& Piironea, 2000; Chuanphongpanich, Suttajit, Phanichphant, Buddhasukh, \& Slrlthunyalug, 2006; Sorensen et al., 2001; Ewald, Fjelkner-Modig, Johansson, Sjoholm, \& Akesson, 1999; Mohammed, 2002; Clifford, 2000; Rao \& Kiran, 2011; Hertog, Hollman, \& Katan, 1992; Lees, Wall, Beveridge, \& Suttill, 1995; Kahkonen, Hopia, \& Heinonen, 2001; Hakkinen, Karenlampi, Mykkanen, \& Torronen, 2000; Heinonen, 
Meyer, \& Frankel, 1998; Currie et al., 2006; Miller \& RiceEvans, 1997; Risch \& Herrmann, 1988; Macheix, Fleuriet, \& Billot, 1990; Kalt, Forney, Martin, \& Prior, 1999; Vollmannova et al., 2009; Lees \& Francis, 1972; SaperS, Phillips, Rudolf, \& Divito, 1983; Sapers, Jones, \& Maher, 1983; Billyk \& Sapers, 1986; Frankel \& Meyer, 1998; Santos-Buelga \& Scalbert, 2000; Mullen, Marks, \& Crozier, 2007; Stohr \& Herrmann, 1975; Chang, Tan, Frankel, \& Barrett, 2000; Tomas-Barberan et al., 2001; RiceEvans, Miller, \& Paganga, 1996; Donovan, Meyer, \& Waterhouse, 1998; Wada \& Ou, 2002; Hakkinen, Karenlampi, Heinonen, Mykkanen, \& Torronen, 1999; Garcia-Viguera, Zafrilla, \& TomasBarberan, 1997; Markowski \& Plocharski, 2006). In milk systems, the non-lipid constituents of ghee residue viz. amino acids, free sugars, free sulphydryl compounds and their interaction products with proteins and phospholipids have antioxidant properties (Guchhait, Arora, \& Rai, 1998). Moreover, some components in skim milk, maillard browning products, $\beta$-carotene, and gossypol, etc. have antioxidative properties, as reported by several research groups (Table 3 and 4). (Harsh, Walker, Schweizer, \& Vivanco, 2002) observed that Ocimum basilicum $L$. (sweet basil) is valuable due to its pharmaceutical properties; for example, the volatile oil produced by the leaves is used as antioxidant. Leal et al. (2008) identified the eugenol, germacreneD, epi-alpha-cadinol, malic acid, tartaric acid, rhamnose, caffeic acid, quinic acid, kaempferol, caffeoylquinic acid and kaempferol 3-O-glucoside as main components in sweet basil leaf extract. Many scientific studies showed that sweet basil extract is a strong radical scavenger and can be considered as a good source of natural antioxidants (Abas, Lajis, Israf, Khozirah, \& Kalsom, 2006).

\section{Limitations of natural antioxidants}

Natural antioxidants are available from raw materials of variable composition (Cuppett, 2001), whereas, synthetic antioxidants are produced as pure substances of constant composition. Application of synthetic antioxidants, unlike natural antioxidants, is relatively easy requiring no substantial modifications of the recipe and process- ing conditions. The amount of natural antioxidant added to food products should be adapted according to analytical results obtained. It is also affected by the processing conditions like pasteurization (change in vitamin E), sterilization, boiling and evaporation which destroys some heat-labile vitamins and reduces the biological value of proteins (Pokorny, 2001).

\subsection{Synthetic antioxidants}

Synthetic antioxidant compounds are widely used in food products to inhibit progress of lipid oxidation. Addition of these to food products is however, prohibited in some countries. The antioxidant effects in milk rely primarily on endogenous compounds (Brien \& Connor, 2003). Some of the more popular synthetic antioxidants used in many countries including India are Butylated Hydroxy Anisole (BHA), Ter-Butyl Hydroquinone or t-buthylhydroquinone (TBHQ), and esters of gallic acid (Yanishlieva-Maslarova, 2001). Butylated Hydroxytoluene (BHT) is very effective in animal fats, low-fat food, fish products, packaging materials, paraffin and mineral oils but is less effective in vegetable oils and may be lost during frying because of its steam volatility ((Gordon \& Kourimska, 1995).

\section{Limitations of synthetic antioxidants}

There are a number of controversies in the use of synthetic antioxidants. Since food additives are subjected to the most stringent toxicological testing procedures, only a few synthetic antioxidants have been used in foods for any length of time.

Since the toxicity of some synthetic antioxidants is not easily assessed, as a result a chemical may be considered safe by a country, tolerated in another country and forbidden in a third one. The carcinogenicity of BHA and BHT in experimental animals has been reported by Hocman (1981). Reports have shown that BHA has carcinogenic effects in non-rodents (pigs, monkeys) and causes lesion formation in the rat stomach whereas BHT has carcinogenic effects in the liver of rats and mice (Botterweck, Verhagen, Goldbohm, Kleinjans, \& van den Brandt, 
Table 3: Antioxidant compounds in selected fruits and berries

\begin{tabular}{|c|c|c|c|}
\hline Source & Antioxidant compound & $\begin{array}{c}\text { Weight } \\
\text { (mg/kg fresh weight) }\end{array}$ & References \\
\hline Apple & $\begin{array}{c}\text { Anthocyanins } \\
\text { Flavanols \& Proanthocyanidins } \\
\text { Flavonols } \\
\text { Hydroxycinnamates } \\
\text { Carotenoids }(\beta \text {-Carotene })\end{array}$ & $\begin{array}{c}4-5 \\
0-15 \\
17-417 \\
263-308 \\
0.4\end{array}$ & $\begin{array}{l}\text { (Heinonen et al., 1989; Hertog et al., 1992); } \\
\text { (Heinonen et al., 1989; Hertog et al., 1992); } \\
\text { (Lees et al., 1995; Kahkonen et al., 2001) } \\
\text { (Markowski \& Plocharski, 2006) }\end{array}$ \\
\hline Bilberries & $\begin{array}{c}\text { Anthocyanins } \\
\text { Flavanols \& Proanthocyanidins } \\
\text { Flavonols } \\
\text { Hydroxycinnamates } \\
\text { Carotenoids }(\beta \text {-Carotene }) \\
\end{array}$ & $\begin{array}{c}3450-4635 \\
13-29 \\
41-195 \\
170-347 \\
0.5 \\
\end{array}$ & $\begin{array}{l}\text { (Heinonen et al., 1989; Kahkonen et al., 2001); } \\
\text { (Hakkinen et al., 2000) }\end{array}$ \\
\hline Blueberries & $\begin{array}{c}\text { Anthocyanins } \\
\text { Flavanols \& Proanthocyanidins } \\
\text { Flavonols } \\
\text { Hydroxycinnamates }\end{array}$ & $\begin{array}{c}3970-4840 \\
63-70 \\
115-139 \\
226-315 \\
\end{array}$ & (Heinonen et al., 1989; Heinonen et al., 1998) \\
\hline Blackcurrant & $\begin{array}{c}\text { Anthocyanins } \\
\text { Flavanols \& Proanthocyanidins } \\
\text { Flavonols } \\
\text { Hydroxycinnamates } \\
\text { Carotenoids }(\beta \text {-Carotene }) \\
\end{array}$ & $\begin{array}{c}130-8100 \\
205-374 \\
133-157 \\
104-167 \\
1 \\
\end{array}$ & $\begin{array}{l}\text { (Heinonen et al., 1989; Hakkinen et al., 2000); } \\
\text { (Kahkonen et al., 2001; Currie et al., 2006) }\end{array}$ \\
\hline Blackcurrant juice & $\begin{array}{l}\text { Anthocyanins } \\
\text { Flavonols } \\
\text { Vitamin C }\end{array}$ & $\begin{array}{c}24 \\
36 \\
380-421\end{array}$ & $\begin{array}{l}\text { (Miller \& RiceEvans, 1997); } \\
\text { (Hakkinen et al., 2000) }\end{array}$ \\
\hline Cherry (sweet, red) & $\begin{array}{c}\text { Anthocyanins } \\
\text { Flavanols \& Proanthocyanidins } \\
\text { Flavonols } \\
\text { Hydroxycinnamates } \\
\text { Carotenoids }(\beta \text {-Carotene }) \\
\end{array}$ & $\begin{array}{c}31-4500 \\
20-63 \\
10-23 \\
100-1900 \\
1.2 \\
\end{array}$ & $\begin{array}{l}\text { (Risch \& Herrmann, 1988; Macheix et al., 1990); } \\
\text { (Heinonen et al., 1989; Heinonen et al., 1998; Kalt et al., 1999); }\end{array}$ \\
\hline Cloudberries & $\begin{array}{c}\text { Anthocyanins } \\
\text { Flavanols \& Proanthocyanidins } \\
\text { Flavonols } \\
\text { Hydroxycinnamates } \\
\text { Carotenoids }(\beta \text {-Carotene }) \\
\end{array}$ & $\begin{array}{c}7-15 \\
2-6 \\
34-90 \\
90-128 \\
1.4 \\
\end{array}$ & (Heinonen et al., 1989; Kahkonen et al., 2001) \\
\hline Cranberries & $\begin{array}{c}\text { Anthocyanins } \\
\text { Flavanols \& Proanthocyanidins } \\
\text { Flavonols } \\
\text { Hydroxycinnamates } \\
\text { Carotenoids }(\beta \text {-Carotene) }\end{array}$ & $\begin{array}{c}460-1720 \\
285 \\
139-334 \\
191 \\
0.2\end{array}$ & $\begin{array}{l}\text { (Vollmannova et al., 2009; Lees \& Francis, 1972); } \\
\text { (SaperS et al., 1983; Sapers et al., 1983; Billyk \& Sapers, 1986); } \\
\text { (Heinonen et al., 1989; Kahkonen et al., 2001); }\end{array}$ \\
\hline Cranberries Juice & Anthocyanins & $18-512$ & (SaperS et al., 1983; Sapers et al., 1983) \\
\hline Grapes (table, red) & $\begin{array}{c}\text { Anthocyanins } \\
\text { Flavanols \& Proanthocyanidins } \\
\text { Flavonols } \\
\text { Hydroxycinnamates }\end{array}$ & $\begin{array}{c}72.5-765 \\
1-160 \\
13-25 \\
5-19\end{array}$ & $\begin{array}{c}\text { (Frankel \& Meyer, 1998); } \\
\text { (Santos-Buelga \& Scalbert, 2000) }\end{array}$ \\
\hline Grapes (wine, red) & $\begin{array}{c}\text { Anthocyanins } \\
\text { Flavanols \& Proanthocyanidins } \\
\text { Flavonols } \\
\text { Hydroxycinnamates } \\
\end{array}$ & $\begin{array}{c}0.6-385 \\
0-500 \\
10-55 \\
4-13 \\
\end{array}$ & $\begin{array}{l}\text { (Frankel, Waterhouse, \& Teissedre, 1995); } \\
\text { (Santos-Buelga \& Scalbert, 2000) }\end{array}$ \\
\hline Grapes (table, white) & $\begin{array}{c}\text { Anthocyanins } \\
\text { Flavanols \& Proanthocyanidins } \\
\text { Flavonols } \\
\text { Hydroxycinnamates }\end{array}$ & $\begin{array}{c}0 \\
0 \\
10-13.5 \\
5.3-5.5\end{array}$ & $\begin{array}{l}\text { (Hertog et al., 1992; Frankel \& Meyer, 1998); } \\
\text { (Mullen et al., 2007). }\end{array}$ \\
\hline Grapes (wine, white) & $\begin{array}{c}\text { Anthocyanins } \\
\text { Flavanols \& Proanthocyanidins } \\
\text { Hydroxycinnamates }\end{array}$ & $\begin{array}{c}0 \\
0-106 \\
1-34\end{array}$ & (Frankel, Waterhouse, \& Teissedre, 1995) \\
\hline Orange & $\begin{array}{c}\text { Flavonols } \\
\text { Hydroxycinnamates } \\
\text { Carotenoids ( } \beta \text {-Carotene) }\end{array}$ & $\begin{array}{c}0-5 \\
136-163 \\
0-5\end{array}$ & $\begin{array}{l}\text { (Stohr \& Herrmann, 1975; Hertog et al., 1992); } \\
\text { (van den Berg et al., 2000) }\end{array}$ \\
\hline Peach & $\begin{array}{c}\text { Anthocyanins } \\
\text { Flavanols \& Proanthocyanidins } \\
\text { Flavonols } \\
\text { Hydroxycinnamates } \\
\text { Carotenoids ( } \beta \text {-Carotene) }\end{array}$ & $\begin{array}{c}0-17.8 \\
24.5-700 \\
0-11.9 \\
54-148 \\
0.9\end{array}$ & $\begin{array}{l}\text { (Heinonen et al., 1989; Chang et al., 2000); } \\
\text { (Tomas-Barberan et al., 2001) }\end{array}$ \\
\hline Plum & $\begin{array}{c}\text { Anthocyanins } \\
\text { Flavanols \& Proanthocyanidins } \\
\text { Flavonols } \\
\text { Hydroxycinnamates }\end{array}$ & $\begin{array}{c}19-76 \\
140-600 \\
5.7-27 \\
500-900\end{array}$ & $\begin{array}{l}\text { (Macheix et al., 1990; RiceEvans et al., 1996); } \\
\text { (Macheix et al., 1990; RiceEvans et al., 1996); } \\
\text { (Donovan et al., 1998; Tomas-Barberan et al., 2001) }\end{array}$ \\
\hline Plum dried (prune) & $\begin{array}{c}\text { Anthocyanins } \\
\text { Flavanols \& Proanthocyanidins } \\
\text { Flavonols } \\
\text { Hydroxycinnamates } \\
\text { Carotenoids }(\beta \text {-Carotene) }\end{array}$ & $\begin{array}{c}0 \\
0 \\
42 \\
1800 \\
1.4\end{array}$ & (Heinonen et al., 1989; Donovan et al., 1998) \\
\hline Raspberries (red) & $\begin{array}{c}\text { Anthocyanins } \\
\text { Flavanols \& Proanthocyanidins } \\
\text { Flavonols } \\
\text { Hydroxycinnamates } \\
\text { Carotenoids }(\beta \text {-Carotene) }\end{array}$ & $\begin{array}{c}200-2200 \\
4-480 \\
6-39 \\
3-35 \\
0.1\end{array}$ & $\begin{array}{l}\text { (Heinonen et al., 1989; Heinonen et al., 1998) } \\
\text { (Wada \& Ou, 2002; Hakkinen et al., 2000); } \\
\text { (Kahkonen et al., 2001). }\end{array}$ \\
\hline Strawberries & $\begin{array}{c}\text { Anthocyanins } \\
\text { Flavanols \& Proanthocyanidins } \\
\text { Flavonols } \\
\text { Hydroxycinnamates } \\
\text { Carotenoids ( } \beta \text {-Carotene) }\end{array}$ & $\begin{array}{c}202-790 \\
9-184 \\
7-174 \\
14-69 \\
0.1\end{array}$ & $\begin{array}{c}\text { (Heinonen et al., 1989; Heinonen et al., 1998; Hakkinen et al., 1999); } \\
\text { (Kahkonen et al., 2001) }\end{array}$ \\
\hline Strawberry jam & $\begin{array}{l}\text { Anthocyanins } \\
\text { Flavonols }\end{array}$ & $\begin{array}{l}-22 \\
11.4\end{array}$ & $\begin{array}{l}\text { (Garcia-Viguera et al., 1997) } \\
\text { (Hakkinen et al., 2000) }\end{array}$ \\
\hline
\end{tabular}


Table 4: Antioxidant compounds in selected vegetables and their products

\begin{tabular}{|c|c|c|c|}
\hline Source & Antioxidant compound & $\begin{array}{c}\text { Weight } \\
\text { (mg/ kg fresh weight) }\end{array}$ & Reference \\
\hline \multirow[t]{4}{*}{ Broccoli } & Flavonols (quercetin) & $15-65$ & (Heinonen et al., 1989; Plumb et al., 1997); \\
\hline & Hydroxy-cinnamates & $62-148$ & (Hollman \& Arts, 2000; Hussein et al., 2000; Matilla et al., 2000) \\
\hline & Carotenoids ( $\beta$-Carotene) & Abr- 27 & (van den Berg et al., 2000; Chuanphongpanich et al., 2006) \\
\hline & Vitamin $\mathrm{C}$ & $750-830$ & \\
\hline \multirow[t]{2}{*}{ Brussels sprouts } & Flavonols (quercetin) & $0-6$ & (Heinonen et al., 1989; Hollman \& Arts, 2000) \\
\hline & Carotenoids ( $\beta$-Carotene) & 4.3 & (Sorensen et al., 2001). \\
\hline Carrots & Carotenoids ( $\beta$-Carotene) & $11-770$ & (van den Berg et al., 2000; Heinonen et al., 1989) \\
\hline \multirow[t]{2}{*}{ Onions } & Flavonols (quercetin) & $340-420$ & (Heinonen et al., 1989; Ewald et al., 1999); \\
\hline & Hydroxy-cinnamates & 0.1 & (Hollman \& Arts, 2000; Mohammed, 2002) \\
\hline Onion (blanched) & Flavonols (quercetin) & $210-290$ & (Ewald et al., 1999) \\
\hline Onion ( fried ) & Flavonols (quercetin) & $220-370$ & (Ewald et al., 1999) \\
\hline \multirow[t]{2}{*}{ Pea } & Flavonols (quercetin) & $1.4-1.6$ & (Heinonen et al., 1989; Ewald et al., 1999) \\
\hline & Carotenoids ( $\beta$-Carotene) & 3.6 & \\
\hline Pea (boiled) & Flavonols (quercetin) & $0.8-1.0$ & (Ewald et al., 1999) \\
\hline Pea (fried) & Flavonols (quercetin) & $1.3-2.0$ & (Ewald et al., 1999) \\
\hline \multirow[t]{2}{*}{ Potatoes } & Hydroxy-cinnamates & 140 & (Heinonen et al., 1989; Clifford, 2000) \\
\hline & Carotenoids ( $\beta$-Carotene) & 0.1 & \\
\hline Spinach & Carotenoids ( $\beta$-Carotene) & $8-240$ & (van den Berg et al., 2000) \\
\hline \multirow[t]{2}{*}{ Tomatoes } & Flavonols (quercetin) & Fev-14 & (Heinonen et al., 1989; Hollman \& Arts, 2000); \\
\hline & Carotenoids ( $\beta$-Carotene) & $0.2-623$ & (Rao \& Kiran, 2011) \\
\hline Tomatoes (juice) & Flavonols (quercetin) & 13 & (Hollman \& Arts, 2000) \\
\hline Tomatoes (ketchup) & Carotenoids ( $\beta$-Carotene) & 99 & (Heinonen et al., 1989) \\
\hline Sweet red pepper & Carotenoids ( $\beta$-Carotene) & $1.2-33$ & (van den Berg et al., 2000) \\
\hline
\end{tabular}

2000). Thus, toxicological studies are crucial in determining the safety of an antioxidant and also in determining the allowable daily intake (ADI) levels. ADIs for widely used antioxidants such as TBHQ, BHA, BHT and gallates have changed over the years mainly because of their toxicological effects in various species. Table 5 (Shahidi \& Zhong, 2001) presents the ADIs allocated by Joint Food and Agriculture Organization $(\mathrm{FAO}) /$ World Health Organization (WHO) Expert Committee on Food Additives (JECFA). Synthetic antioxidants have limitations to be used in food requiring severe thermal treatment, as the gallates decompose when heated above 148 ${ }^{o} \mathrm{C}$.

\section{Mechanism of Action}

Antioxidants slow down the oxidation rates of foods by a combination of scavenging free radicals, chelating pro-oxidative metals, quenching singlet oxygen and photo-sensitizers, and inactivating lipoxygenase (LOX).

\subsection{Free radical scavenging}

The effectiveness of antioxidants to scavenge free radicals in foods depends on the bond dissocia- tion energy between oxygen and a phenolic hydrogen, and reduction potential and delocalization of the antioxidant radicals (Choe \& Min, 2006; Cao et al., 2007).

Vitamin $\mathrm{E}$ or $\alpha$-tocopherol is a methylated phenol required in the human diet. Phenolic compounds primarily inhibit lipid oxidation through their ability to scavenge free radicals and convert the resulting phenolic radicals into a low-energy form that does not further promote oxidation. The synergistic effect of tocopherol and ascorbic acid is shown in Figure 1. The tocopherol radical sometimes reacts with lipid peroxy radicals at very high concentration and produces tocopherol peroxide. Tocopherol peroxide produces two isomers of epoxy- $8 \alpha$-hydroperoxytocopherone which becomes epoxyquinones upon hydrolysis (Liebler, Baker, \& Kaysen, 1990). This reaction produces alkoxy radicals, instead of peroxy radicals, and loses only tocopherol. Since there is no net decrease in free radicals in the system, tocopherol does not act as an antioxidant (Choe \& Min, 2009). 
Table 5: ADIs of some antioxidants permitted in foods (Shahidi \& Zhong, 2001).

\begin{tabular}{cc}
\hline Antioxidant & ADI ( mg/kg bw)* \\
\hline Propyl gallate (PG) & $0-2.5$ \\
Butylated hydroxyanisole, BHA (E320) & $0-0.5$ \\
Butylated hydroxytoluene, BHT (E321) & $0-0.3$ \\
Tertiary-butyhydroqiunone, TBHQ & $0-0.2$ \\
Tocopherols & $0.15-2.0$ \\
Gum guaiac & $0-2.5$ \\
Bhoxyquin & $0-0.08$ \\
Phosphates & $0-70.0$ \\
Tartaric acid & 2.5 \\
Citric acid & $0-30.0$ \\
Lecithin & Not limited \\
Ascorbic acid & Not limited \\
Sulphites (as sulphur dioxide) & Not limited \\
Ascorbyl palmitate or ascorbyl strearate (or the sum of both) & $0-0.7$ \\
*ADI, acceptable daily intake; bw, body weight; E number refers to food additives.
\end{tabular}

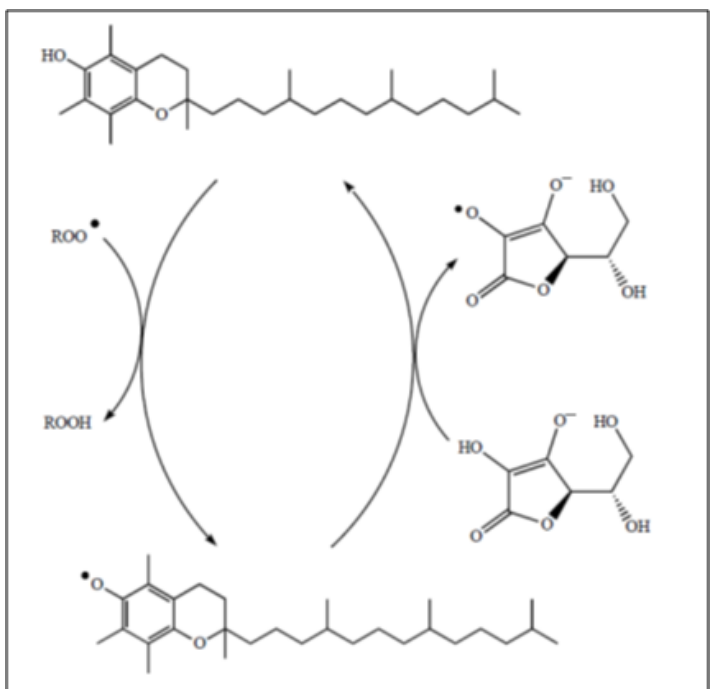

Figure 1: Synergistic effect of tocopherol and ascorbic acid (Torres, Kunamneni, Ballesteros, \& Plou, 2008).

\subsection{Pro-oxidative metals as chelating agents}

Metals reduce the activation energy of the oxidation reaction, especially in the initiation step, to accelerate oil oxidation (Jadhav, Nimbalkar, Kulkami, \& Madhavi, 1996). The activation energies for the autoxidation of refined bleached and deodorized soybean, sunflower and olive oils were $17.6,19.0$ and $12.5 \mathrm{kcal} / \mathrm{mol}$, respectively (Lee, Kim, \& Choe, 2007). Metals catalyze food radical formation by abstracting hydrogen. They also produce hydroxyl radicals by catalyzing decomposition of hydrogen peroxide (Andersson, 1998) or hydroperoxides (Benjelloun, Talou, Delmas, \& Gaset, 1991). Ferric ions decrease the oxidative stability of olive oil by decomposing phenolic antioxidants such as caffeic acid (Keceli \& Gordon, 2002).

Flavonoids are known to exhibit a strong metal chelating activity in addition to their antioxidant properties, with the arrangement of 4-keto and $5-\mathrm{OH}$, or 3' and 4'-OH substituents resulting in the formation of chelating complexes between flavonoids and divalent cations (Cheng \& Breen, 2000). Kolak, Ozturk, Ozgokce, and Ulubelen (2006) reported that extract of roots of Delphinium linearilobum (Trautv.) $N$. contains the alkaloid lycoctonine which exhibits the highest metal chelating activity. 


\subsection{Quenching Singlet Oxygen}

Carotenoids with nine or more conjugated double bonds are good singlet oxygen quenchers by energy transfer. The singlet oxygen quenching activity of carotenoids depends on the number of conjugated double bonds in the structure (Min \& Boff, 2002; Foss et al., 2004) and the substituent in the $\beta$-ionone ring (Di Mascio \& Sies, 1989). $\beta$ carotene and lycopene which have 11 conjugated double bonds are more effective singlet oxygen quenchers than lutein which has 10 conjugated double bonds (Viljanen, Sunberg, Ohshima, \& Heinonen, 2002). The presence of oxo and conjugated keto-groups, or cyclopentane ring in the structure increases the singlet oxygen quenching ability (Di Mascio \& Sies, 1989). $\beta$-carotene, tocopherols, ascorbic acid, amino acids, peptides and phenolics are oxidized by singlet oxygen and they are all chemical quenchers of singlet oxygen (Michaeli \& Feitelson, 1994).

\section{Addition of Antioxidative Compounds to Food}

The applications of antioxidants are widespread in the food industry (Zhang, Zhu, \& Wang, 2004). Many studies are focused on utilizing more effective antioxidants from natural sources (McCarthy et al., 2001). Spices including cloves, cinnamon, black pepper, turmeric, ginger, garlic and onion are used widely and exhibit antioxidative activities in a variety of food systems in fresh and dried form (Ramanathan \& DAS, 1993; Thorat, Mohapatra, Sutar, Kapdi, \& Jagtap, 2012).

\subsection{Inhibition of oxidation in meat and meat products}

The shelf life of processed meat can be extended by using antioxidants and proper packaging materials. Because of the growing consensus on the potential health hazard posed by synthetic antioxidants (Jones, 1992), there is a renewed interest in the increased use of naturally occurring antioxidants. Spice and herb extracts have been reported to contain compounds with antioxidant activity, when used in food systems (Fereidoon \& Champaign, 1997).
Antioxidant properties of natural plant extracts in meat were reported by Ahn, Grun, and Fernando (2002). Besides spices, extracts formed from the condensation of sugar and amino acids have been reported to possess promising antioxidant activity (Wijewickreme \& Kitts, 1998; Bailey, Shin Lee, \& Dupy, 1987; Chuyen, 1998; Lingnert \& Eriksson, 1981). One of the naturally occurring antioxidants most widely used in the meat industry is ascorbic acid, with a varied chemistry. Ascorbic acid and its esters function as antioxidants by protecting double bonds and scavenging oxygen (St. Angelo, Vercellotti, Jacks, \& Legendre, 1996; Verma \& Sahoo, 2000). It has complex multifunctional effects. In cured meats, ascorbic acid can accelerate color development, inhibit nitrosamine formation, and prevent oxidation and color fading. In fresh meat it is used to prevent oxidation and color fading during storage.

\subsection{Inhibition of oxidation in meat and meat products}

Milk and dairy products contain several antioxidants components endogenously, i.e. tocopherols, ascorbic acid, carotenoids, thiol groups of skim milk, and some products of maillard reaction (Fox \& McSweeney, 1998). The reaction of oxygen with unsaturated fatty acids is the major means of deterioration in ghee and almost all fat-rich dairy products. Several authors have shown that the addition of certain milk components prior to or after heat treatment will markedly slow down the autoxidation process in ghee and dairy products (Shantilal, 1984). Also some natural components added to dairy products like ice cream, flavored milk, etc. during or after processing have proven antioxidant activity including amla (Indian gooseberry) juice, aromatic herbs (rosemary, sage, fennel and rue), betel, curry and drumstick leaves, mango seed kernel, onion skin extract, tulsi (Indian sacred basil) leaves, sorghum grain powder, orange peel and black cumin, ragi powder, soybean seed phospholipids etc (Trivedi, 2008). 
$90 \mid$ Thorat et al.

\subsection{Inhibition of lipid oxidation}

The relentless intrusion of oxygen and pervasive nature of initiating pro-oxidants, such as preformed peroxides, make it virtually impossible to prevent oxidation deterioration in general. The obvious corollary is that we must try to minimize the initiation of oxidation as well as retard the propagation reaction in order to extend the useful life time of affected food product. This oxidative deterioration can be inhibited by removal of reactants $\left(\mathrm{O}_{2}\right.$ present in air through packing) and certain conditions such as light (YanishlievaMaslarova, 2001) and metals (copper, iron and nickel) which act as pro-oxidants (Fox \& McSweeney, 1998) and promote the oxidation reaction. The use of antioxidants, which are usually operative at the propagation level, will slow down or inhibit the oxidation process (Gunstone \& Honorary, 2004).

Extracts rich in antioxidative compounds from natural sources such as rapeseed oil byproduct extracts (Thiyam, Kuhlmann, Stockmann, \& Schwarz, 2004), rice bran (Iqbal, Bhanger, \& Anwar, 2005) and red grape marc extracts (Bonilla, Mayen, Merida, \& Medina, 1999) have been reported to be used as endogenous antioxidants instead of commercial antioxidants to stabilize refined oils. Jayathilakan, Sharma, Radhakrishna, and Bawa (2007) reported that natural antioxidants, e.g. spices and ascorbic acid, acted as a promising alternative to synthetic antioxidants in controlling lipid oxidation and thus can enhance the stability of lipids and, in turn, products.

Vegetable oils are rather difficult to stabilize because of their high content of polyunsaturated fatty acids. Their advantage is the presence of natural antioxidants which, in edible oils, is mainly tocopherols. An addition of phenolic antioxidants usually shows limited efficacy, but the addition of synergists is helpful. Ascorbyl palmitate, phospholipids or organic polyvalent acids are useful as inhibitors in vegetable oils (Frankel, Huang, Kanner, \& German, 1994). Gharby, Harhar, Guillaume, Haddad, and Charrouf (2012) discovered that phospholipids are a new and essential type of oil component participating in the excellent oxidative stability of edible argan oil, in addition to the Maillard reaction products, phenols and tocopherols.

\section{Processing and Purification of Antioxidants}

The growing interest in natural antioxidant compounds has resulted in overwhelming relevant scientific information. Numerous epidemiological studies demonstrating health promoting properties attributed to the antioxidants and phytochemicals present in the natural sources (David, Chirinos, \& Pedreschi, 2008) have attracted the attention of many food manufacturers to produce healthy foods. Many components of milk and plants possessing antioxidant activities are used in their natural form, such as skim milk concentrates, ghee residues, phospholipids, butter milk solids, spices, betel and curry leaves, carotenes, etc. The preliminary processing of such food components may be drying (in the case of leaves or stems), milling of dried material or some other mechanical treatment. The content of active antioxidants in natural materials is usually rather low such that large additions would be necessary to obtain a significant improvement in stability against oxidation. Theoretically, it is possible to prepare nearly pure or entirely pure substances by liquid chromatography, repeated crystallization or other procedures, but further purification is not recommended.

The resulting pure antioxidants would be very expensive in comparison with synthetic antioxidants; however, such large additions could have a negative effect on the flavor or functional properties of the product. It is often useful to prepare more concentrated materials (Schmidt \& Pokorny, 2001).

\section{Extraction and Identification of Selected Natural Antioxidants}

There are various processes like solvent extraction, molecular distillation, and supercritical $\mathrm{CO}_{2}$ extraction which are commercially used for the recovery of tocopherols, depending on the form of their natural sources. The first two processes have inherent drawbacks of thermal degradation and/or residual solvent, whereas the third 
method offers the advantage of selective recovery of a truly natural form of mixed tocopherols for vitamin E activity. A common feature of extraction methods is their suitability to only one plant material for certain phenolic acids or certain forms of phenolic acids. Although there are numerous methods for extraction of phenolic compounds from plant material, an optimized and validated method for extraction of a variety of phenolic compounds in different plant foods is lacking (Matilla \& Kumpulainen, 2002).

\subsection{Solvent extraction}

Extraction of plant phenols has be carried out using various solvents such as methanol, ethanol, ethyl acetate, acetone and water at different concentrations (Peckic, Kovac, Alonso, \& Revilla, 1998). The proanthocyanidins, which are oligomers of the catechin and epicatechin are highly soluble in ethyl acetate. The seeds of grapes have a higher content of proanthocyanidins than the rest of the grape. The yield of proanthocyanidins was 2.3 times higher using ethyl acetate and water $(9: 1)$ than the yield using acetone and water $(2: 3)$. It was concluded that ethyl acetate and water selectively extracts proanthocyanidins from grape seeds. Extractions of the grape pomace have been carried out using ethanol and water (80:20). The pomace extracts yielded quercetin, catechin, gallic acid and kaempferol compounds. From this study transcaftaric acid was found to be the most abundant compound present in the grape pomace (Foo \& Lu, 1999). Cocoa bean husk powder and especially water and alcohol extracts were reported as potential antioxidants. Methanolic extracts of cottonseed exhibited antioxidant activity attributed mainly to flavonoids (Whittern, Miller, \& Pratt, 1984).

Results obtained by successive extractions of various raw materials with different solvents further indicated that the choice of the appropriate solvent depends on the raw material and the nature of the antioxidants it contains. Thus, in a sequential extraction of olive rape with hexane acetone and ethanol, the hexane extract, despite amounting to $9 \%$ of the dried rape, had very few polyphenols and lower activity than either the acetone or the ethanol extract, which had similar behavior and amounted to $4 \%$ and $7 \%$ of the dried rape, respectively (Sheabar \& Neeman, 1988).

\subsection{Supercritical fluid extraction (SFE)}

Extraction of antioxidants is mostly done by solvent extraction method; however supercritical $\mathrm{CO}_{2}$ extraction techniques are also being practiced more recently in the pressure range of 200 - 400 bar (Lee, Chung, \& Park, 1991). Supercritical fluid extraction (SFE) is interesting for processing natural products because it produces extracts without organic residues, and the temperature of the process can be low, thus preserving thermo-sensitive compounds. SFE involves a high mass-transfer rate at relatively low temperatures, which is the major reason for the choice of this technique for extracting essential oils such as oleoresins, and other active principles where the final product quality is of great importance. Recently, the use of subcritical water for extraction has been exploited because by varying the temperature and the pressure of the water, the dielectric constant approached very closely the dielectric constants of some organic compounds as methanol, ethanol, butanone, polyaromatic hydrocarbons, phenol, benzene, and others (Reinoso, Moure, Dominguez, \& Parajo, 2006). Subcritical water can produce extracts with a variety of organic substances with linear or ramified chains, showing the effectiveness of water as a solvent for hydrophobic organic composite extraction, due to the polarity of water measured by its dielectric constant (Miller, Hawthorne, Gizir, \& Clifford, 1998).

Leal et al. (2008) used supercritical technology to obtain extracts from sweet basil with $\mathrm{CO}_{2}$ and the co-solvent $\mathrm{H}_{2} \mathrm{O}$. At $20 \%$ of co-solvent the largest global yield was detected at $30 \mathrm{Mpa}$ and $303 \mathrm{~K}$ (24\%, dry basis). Sweet basil extracts obtained by supercritical technology exhibited 96-100\% antioxidant activity compared to $\beta$-carotene.

Lee et al. (1991) examined the feasibility of extracting $\alpha$-tocopherol from soybean sludge with $\mathrm{SC}-\mathrm{CO}_{2}$ at a temperature ranging from 35 to 70

\begin{tabular}{l|l|l|l} 
IJFS & April 2013 & Volume 2 & pages 81-104
\end{tabular} 
${ }^{\circ} \mathrm{C}$ and at a pressure ranging from 200 to 400 bar. They reported that a simple batch process could be utilized to recover tocopherols of $40 \%$ concentration from the esterified sludge initially containing $14 \%$ tocopherols. The esterified soybean sludge was found to be 4 to 6 times more soluble in $\mathrm{SC}-\mathrm{CO}_{2}$ than the sterol-removed soybean sludge (Lee et al., 1991). For the extraction of Mentha spicata, Almeida, Mezzomo, and Ferreira (2012) used SC- $\mathrm{CO}_{2}$ with highest yield $(2.38 \% \mathrm{w} / \mathrm{w})$, at $50{ }^{\circ} \mathrm{C}, 300$ bar. Laroze, DiazReinoso, Moure, Elvira Zuniga, and Dominguez (2010) used both SC-CO $\mathrm{CO}_{2}$ and conventional solvent extraction techniques for extraction of anthocyanins, proanthocyanidins, flavonols, catechins, benzoic and cinnamic acids from the solid residues generated from rosemary, blueberry, cranberry and raspberry. The highest phenolic content was obtained at low pressure, 75100 bar from cranberry and blueberry, and at 150-200 bar from raspberry.

\subsection{Microwave-assisted extraction of antioxidants}

Microwave-assisted extraction (MAE) is a novel process that uses microwave energy to heat the solvents and the sample to increase the mass transfer rate of the solutes from the matrix into the solvent. The combination of solvents and heat is expected to increase the extraction yield as compared to other methods (Nuchter, Ondruschka, Hoffmann, \& Tied, 2004). Because of the heat produced, microwave-assisted solvent extraction takes 10 to 30 minutes, whereas other methods can take hours or days to complete the extraction process. The amount of solvent used in microwave extraction is also considerably less than the amount used in other extraction processes (Shah, Richter, \& Kingston, 2002). MAE is a relatively new extraction technique and has been successfully employed to extract tea polyphenols and tea caffeine from green tea leaves (Pan, Niu, \& Liu, 2003), piperine from black pepper (Raman \& Gaikar, 2002), capsaivinoids from capsicum (Williams, Raghavan, Orsat, \& Dai, 2002), phenolic compounds from grape seeds (Hong, Yaylayan, Raghavan, Pare, \& Belanger, 2001), puerarin from the herbal medicine radix puerariae (Guo et al., 2001), and color pigments from paprika (Kiss et al., 2000). Duvernay, Assad, Sabliov, Lima, and Xu (2005) used microwave extraction successfully to extract vitamin $\mathrm{E}$ from rice bran. Over a temperature range of $80{ }^{\circ} \mathrm{C}$ to $140{ }^{\circ} \mathrm{C}$, an increase of $104 \%$ vitamin $\mathrm{E}$ yield occurred. It was found that at lower temperature, time had little to no effect on yield.

Perino-Issartier, e Huma, Abert-Vian, and Chemat (2011) studied the solvent-free MAE of antioxidants from sea buckthorn food byproducts. The method extracted valuable flavonols in a very short time $(15 \mathrm{~min})$, clearly showing the extraction of higher content of reducing compounds which enhance the antioxidant activity of extracts.

\subsection{Ultrasonic extraction of antioxidants}

High-intensity ultrasound has been used for preservation, cleaning of equipment, emulsification, accelerated drying and freezing, and most recently, for extraction of various compounds from food materials. Ultrasound-assisted extraction (UAE) is an attractive means of extraction as it is much simpler, faster \& more effective when compared with other methods (e.g. supercritical fluid extraction) and has low instrumental requirements. Extraction is carried out using an ultrasonic probe system or an ultrasonic bath. Rostagno, Palma, and Barroso (2003) used UAE to extract isoflavones from soybeans. They found that maximum recoveries occurred when using 50 $\% \mathrm{EtOH}$ as the extraction solvent at $60{ }^{\circ} \mathrm{C}$ for 20 min.

Additionally, Wang, Zhao, Zhao, and Jiang (2007) were able to utilize UAE to extract phenolic compounds from wheat bran. The optimized conditions were $64 \% \mathrm{EtOH}, 60{ }^{\circ} \mathrm{C}$ and $25 \mathrm{~min}$ for extraction solvent, temperature and time, respectively. Similarly, Rodrigues and Pinto (2007) reported that extraction time was the most significant factor influencing extraction efficiency. Maximum recoveries of total phenolics (406 mg/L) occurred at an ultrasound extraction time of $60 \mathrm{~min}$. 


\subsection{High hydrostatic pressure extraction of antioxidants}

There are various processes for the extraction of required phytochemicals from plants including MAE, ultrasonic extraction, supercritical fluid extraction, subcritical water extraction and pressurized liquid extraction. The main disadvantages of these processes are either the degradation of the phytochemicals present in the plant due to the methodology involved in extraction such as high temperature of the solvent as in the case of pressurized liquid extraction and microwave-assisted extraction or the cost incurred as in supercritical fluid extraction (Kaufmann \& Christen, 2002). A modified version of high hydrostatic pressure extraction (HHPE) has been developed to extract the phytochemicals without much effect on their properties. The sample is placed in extraction vessel and optimized extraction process parameters are applied. In this process, parameters such as pressure, temperature and time duration can be varied according to the biology of the plant in order to obtain maximum yield. By HHPE, a single component of high purity can be easily obtained. Strong, weak, and non-polar compounds can all be extracted by using different solvents. Saving energy and safety are also advantages of HHPE. HHPE can be used as a tool for drug discovery, allowing chemical reactions to occur under more suitable conditions. HHPE was found to give higher yield of essential components when compared with ultrasonic and heat reflux extractions (Zhang et al., 2004).

Kumar, Chu, Krishnaiah, and Bono (2006) studied the modified version of HHPE for extraction of antioxidants from $M$. citrifolia fruit. It was found that the antioxidant activity of the extracts increased with an increase in pressure. The optimum antioxidant activity was achieved using an extraction process at $58^{\circ} \mathrm{C}$ for 5 hours at 25 bar.

\section{Legal Aspects of Antioxidants}

Antioxidants should satisfy several requirements before being accepted for incorporation into food products. Different antioxidants show substan- tially different antioxidant effectiveness in different fats and oils and food systems due to their different molecular structures (Mikova, 2002). However, safety and acceptability factors should be considered prior to their introduction to the food system. Antioxidants to be used in food applications should posses certain properties having a positive influence on foods and consumers, such as solubility in fat, no harmful physiological effects, no objectionable flavour or color contribution to the fat, effective in low concentration, effective at a temperature between 25 and $30{ }^{\circ} \mathrm{C}$, stable to $\mathrm{pH}$ change, no destruction during processing, readily available and economical (Pokorny, 2001).

\subsection{Legal aspects of natural antioxidants}

The use of antioxidants in food products is governed by regulatory laws of the individual country or by internal standards. Even though many natural and synthetic compounds have antioxidant properties, only a few of them have been accepted as generally recognized as safe (GRAS) substances for use in food products by international bodies such as JECFA and the European Community's Scientific Committee for Food (SCF). Antioxidants are extensively tested for the absence of carcinogenicity and other toxic effects in themselves, in their oxidized forms and in their reaction products with food constituents. Toxicological studies are crucial in determining the safety of an antioxidant and also in determining the ADI levels.

\subsection{Legal aspects of synthetic antioxidants}

ADI levels for widely used antioxidants such as $\mathrm{BHA}$ and gallates have changed over the years mainly because of their toxicological effects in various species (Pokorny, 2001). Generally, addition of antioxidants (synthetic) is not allowed in dairy products and therefore, their stability must rely on components present in the milk. According to the PFA Act only a few synthetic antioxidants have gained legal sanction including BHA, NDGA, hydroquinone, citric acid and ascorbyl 
palmitate. Among these different antioxidants, the legal permissible limit for BHA is $0.02 \%$ in ghee and butter. Fat spread may also contain BHA and TBHQ in concentrations not exceeding $0.2 \%$ by weight on fat basis. Dairy-based sweet meats like Rasgolla and Peda may contain BHA not exceeding $0.02 \%$, calculated on the fat basis. Also gallates are used in milk fat/anhydrous milk fat/ butter oils at concentrations not exceeding $0.1 \%$ of milk fat (PFA - Prevention of Food Adulteration, 2008).

According to Codex Alimentarius, the antioxidants covered by the standard and their maximum levels of use are based in part on the food additive provisions of previously established Codex Commodity Standards, or upon the request of governments after subjecting the requested maximum levels to an appropriate method which would verify the compatibility of a proposed maximum level with the ADI (Codex Alimentations, 2008). The results of scientific studies are controversial with links suggested between synthetic antioxidants and cancer. Scientific studies that have been carried out on rats have required very high levels of $\mathrm{BHA}$ to trigger cancer levels that are not relevant to normal human consumption. The type of cancer found in rats and mice was also not relevant to any digestion mechanism in humans. So scientists conclude that these findings are not relevant to humans (Food Safety, 2008).

The best method of application of natural antioxidants is to use natural food components (e.g. cereals, nuts, fruits and vegetables) because they are regarded as safe and no special approval for their application is necessary. Another possibility is to use natural food ingredients such as spices (Pokorny, 2001).

Natural antioxidants are available in most of the multivitamins and there are no adverse reports or deaths through using multivitamins. However, 10 to 15 cases of vitamin A toxic reactions are reported per year in the United States, usually at doses $>100,000 \mathrm{IU} /$ day for months or years (about 40 times the recommended dietary allowance) (Allen \& Haskell, 2002; Meyers, Maloley, \& Weeks, 1996). No adverse effects have been reported for $\beta$-carotene. Ascorbic acid toxic reactions are rare at dosages $<4 \mathrm{~g} / \mathrm{d}$. Selenium was associated with a $9 \%$ lower risk of death.
Selenium is toxic if its consumption is more than $6 \mathrm{mg} /$ day. So far, there are no reports of adverse effects of other antioxidants; however, the safety of antioxidant use is not well documented (Vijaya \& Vidyasagar, 2009). Natural antioxidants from herbs and spices occupy a special position in foods as traditional food ingredients and hence are appropriately used directly for their antioxidant characteristics. If they are applied to foods, they do not need to be declared as antioxidants (PFA - Prevention of Food Adulteration, 2008). The safety of natural antioxidants should not to be taken for granted. Caution must be exercised, since numerous natural products are potential carcinogens, mutagens or teratogens and the safety of many natural compounds with antioxidant activity has not yet been established. A case in point is NDGA which was used extensively as an antioxidant earlier this century. NDGA is a natural constituent of the creosote bush, which was removed from GRAS status when unfavorable toxicological results were reported (Reishe \& Eitemmiller, 2008). In India, as well as in European legislation, there are no legal rules regarding declaration of natural antioxidants present in food, the permissible safe limit for consumption and at what concentration they will act as pro-oxidants and synergists; there is also a need to determine daily intake doses which should be declared on the product labels.

\section{Conclusions}

Antioxidants play a major role in preventing oxidation of lipids in foods as well in humans. Synthetic antioxidants are involved in the triggering of diseases in humans at a certain concentration. Many components of milk and plants have antioxidative properties which can be manipulated for use in foods. The toxicological effects of food antioxidants have been the focus of controversy in recent years. Better understanding of the role of natural antioxidants on food stability and human health is required. There are no safety regulatory controls over natural antioxidants at higher concentrations as they may also cause problems to human health. Toxicological studies are mainly carried out to establish the no-effect level for an ADI for humans. 
Antioxidants, their properties, uses in food products and their legal implications $\mid 95$

The laws must be modified to ensure the integration of these issues in determining the criteria for safety. It must be known about the long term consequences of more doses of antioxidants. The regulatory and judicial system must be prepared to accept this expanded role for food in the matrix of national life and the international market.

\section{Acknowledgements}

The authors want to thank Anand Agricultural University, Anand, India for providing necessary infrastructural facilities for the preparation of this manuscript.

\section{References}

Abas, F, Lajis, N., Israf, D., Khozirah, S, \& Kalsom, Y. (2006). Antioxidant and nitric oxide inhibition activities of selected Malay traditional vegetables. Food Chemistry, 95(4), 566-573. doi:10 . $1016 / \mathrm{j}$. foodchem.2005.01.034

Adegoke, G., Kumar, M., Krishna, A., Varadaraj, M., Sambaiah, K, \& Lokesh, B. (1998). Antioxidants and lipid oxidation in foods - A critical appraisal. Journal of Food Science and Technology-Mysore, 35(4), 283-298.

Ahn, J, Grun, I., \& Fernando, L. (2002). Antioxidant properties of natural plant extracts containing polyphenolic compounds in cooked ground beef. Journal of Food Science, 67(4), 1364-1369. doi:10.1111/j . 1365-2621.2002.tb10290.x

Ali, B., Mohamed, H., Rafik, B., Imen, L., Yosra, T. E., \& Moncef, N. (2009). Antioxidant and free radical-scavenging activities of smooth hound (mustelus mustelus) muscle protein hydrolysates obtained by gastrointestinal proteases. Food Chemistry, 114(4), 1198-1205.

Allen, L., \& Haskell, M. (2002). Estimating the potential for vitamin A toxicity in women and young children. Journal of Nutrition, 132(9, S), 2907S-2919S. 20th International-Vitamin-A-Consultative-
Group Meeting, HANOI, VIETNAM, FEB 12-15, 2001.

Almeida, P. P., Mezzomo, N., \& Ferreira, S. R. S. (2012). Extraction of Mentha spicata L. Volatile Compounds: Evaluation of Process Parameters and Extract Composition. Food And Bioprocess Technology, 5(2), 548-559. doi:10.1007/s11947-010-0356-y

Andersson, K. (1998). Influence of reduced oxygen concentrations on lipid oxidation in food during storage [d.phil diss.] Chalmers Reproservice. Sweden: Chalmers University of Technology and the Swedish Institute for Food and Biotechnology.

Avila-Sosa, R., Guadalupe Gastelum-Franco, M., Camacho-Davila, A., Vinicio TorresMunoz, J., \& Virginia Nevarez-Moorillon, G. (2010). Extracts of Mexican Oregano (Lippia berlandieri Schauer) with Antioxidant and Antimicrobial Activity. Food and Bioprocess Technology, 3(3), 434-440. doi:10.1007/s11947-008-0085-7

Bailey, M., Shin Lee, S., \& Dupy, H. (1987). Maillard reaction products in warmed overflavour of meat. Orland, FL: Academic Press Inc.

Benjelloun, B, Talou, T, Delmas, M, \& Gaset, A. (1991). Oxidation of Rapeseed Oil - Effect of Metal Traces. Journal of the American Oil Chemists Society, 68(3), 210-211. doi:10.1007/BF02657772

Billyk, A., \& Sapers, G. (1986). Varietal differences in the quercetin, kaempherol and myricetin contents of highbush blueberry, cranberry and thornless blackberry fruits. Journal of Agriculture and Food Chemistry, 34 (4), 585-588.

Bodnar, R. J. (2010). Endogenous opiates and behavior: 2009. Peptides, 31(12), 23252359. doi:10.1016/j.peptides.2010.09.016

Bonilla, F, Mayen, M, Merida, J, \& Medina, M. (1999). Extraction of phenolic compounds from red grape marc for use as food lipid antioxidants. Food Chemistry, 66(2), 209 215. doi:10.1016/S0308-8146(99)00046-1

Botterweck, A., Verhagen, H, Goldbohm, R., Kleinjans, J, \& van den Brandt, P. (2000). Intake of butylated hydroxyanisole and butylated hydroxytoluene and stomach cancer risk: Results from analyses in the 
Netherlands cohort study. Food and Chemical Toxicology, 38(7), 599-605. doi:10 . 1016/S0278-6915(00)00042-9

Bradley, D., \& Min, D. (1992). Singlet Oxygen Oxidation of Foods. Critical Reviews in Food Science and Nutrition, 31 (3), 211236.

Brien, N., \& Connor, T. (2003). Lipid oxidation. In . J.W. Fuquay \& P.F. Fox (eds.). Encyclopedia of Dairy Science. p.1600-1604. New York: Academic Press, Elsevier Science.

Calabrese, V, \& Maines, M. (2006). Antiaging medicine: Antioxidants and aging. Antioxidants 8 Redox Signaling, 8(3-4), 362-364. doi:10.1089/ars.2006.8.362

Cao, W., Chen, W., Sun, S., Guo, P., Song, J., \& Tian, C. (2007). Investigating the antioxidant mechanism of violacein by density functional theory method. Journal of Molecular Structure-Theochem, 817(1-3), 1-4. doi:10.1016/j.theochem.2007.04.022

Castillo, M., Ferrigno, A., Acampa, I., Borrelli, R. C., Olano, A., Martínez-Rodríguez, A., \& Fogliano, V. (2007). In vitro release of angiotensin-converting enzyme inhibitors, peroxyl-radical scavengers and antibacterial compounds by enzymatic hydrolysis of glycated gluten. Journal of Cereal Science, 45(3), 327 -334. doi:10.1016/j.jcs.2006.09. 005

Chang, S, Tan, C, Frankel, E., \& Barrett, D. (2000). Low-density lipoprotein antioxidant activity of phenolic compounds and polyphenol oxidase activity in selected clingstone peach cultivars. Journal of Agricultural and Food Chemistry, 48(2), 147151. doi:10.1021/jf9904564

Cheng, I., \& Breen, K. (2000). On the ability of four flavonoids, baicilein, luteolin, naringenin, and quercetin, to suppress the fenton reaction of the iron-ATP complex. Biometals, 13(1), 77-83. doi:10.1023/A : 1009229429250

Choe, E., \& Min, D. B. (2007). Chemistry of deep-fat frying oils. Journal of Food Science, 72(5), R77-R86. doi:10.1111/j.17503841.2007.00352.x

Choe, E, \& Min, D. (2005). Chemistry and reactions of reactive oxygen species in foods.
Journal of Food Science, 70(9), R142R159.

Choe, E., \& Min, D. B. (2006). Mechanisms and factors for edible oil oxidation. Comprehensive Reviews in Food Science and Food Safety, 5(4), 169-186. doi:10.1111/j.15414337.2006.00009.x

Choe, E., \& Min, D. B. (2009). Mechanisms of Antioxidants in the Oxidation of Foods. Comprehensive Reviews in Food Science and Food Safety, 8(4), 345-358. doi:10 . 1111/j.1541-4337.2009.00085.x

Chuanphongpanich, S., Suttajit, M., Phanichphant, S., Buddhasukh, D., \& Slrlthunyalug, B. (2006). Antioxidant capacity of broccoli seeds grown in thailand. Chiang Mai Journal of Science, 33(1), 117-122.

Chuyen, N. (1998). Maillard reaction and food processing - Application aspects. In Shahidi, F and Ho, CT and vanChuyen, N (Ed.), Process-Induced Chemical Changes in Food (Vol. 434, 213-235). Advances in Experimental Medicine and Biology. Pacifichem 1995 Conference, HONOLULU, HI, DEC 17-22, 1995.

Clifford, M. (2000). Chlorogenic acids and other cinnamates - nature, occurrence, dietary burden, absorption and metabolism. Journal of the Science of Food and Agriculture, 80(7), 1033-1043. doi:10.1002/(SICI)10970010(20000515) 80:7〈1033::AID- JSFA595〉 3.3. CO;2-K

Codex Alimentations. (2008). STAN 256- 2007 accessed on 23 January 2013. Retrieved from http://www.codexalimentarius.net/ CODEX

Cumby, N., Zhong, Y., Naczk, M., \& Shahidi, F. (2008). Antioxidant activity and waterholding capacity of canola protein hydrolysates. Food Chemistry, 109(1), 144148. doi:10.1016/j.foodchem.2007.12.039

Cuppett, L., Susan. (2001). The use of natural antioxidants in food products of animal origin. In J. Pokorny, N. Yanishlieva \& M. Gordon (eds.). Antioxidants in food practical applications p.284-310. Cambridge: CRC press, Woodhead publishing Ltd.

Currie, A., Langford, G., McGhie, T., Apiolaza, A., Snelling, C., Braithewaite, B., \& Vather, R. (2006). Inheritance of an- 
tioxidants in a new zealand blackcurrant (ribes nigrum l.) population. In Proceedings of the 13th Australasian Plant Breeding Conference. Paper presented at $13^{\text {th }}$ Australasian Plant Breeding Conference, held at Christchurch, New Zealand, 18-21 April. (pp. 218-225). New Zealand: New Zealand Grassland Association.

David, C., Chirinos, R., \& Pedreschi, R. (2008). Extraction, recovery and purification of natural antioxidants from andean crops. Electronic Journal of Environmental Agricultural and Food Chemistry, 7(8), 32213225 .

Di Mascio, S., P.and Kaiser, \& Sies, H. (1989). Lycopene as the most efficient biological carotenoid singlet oxygen quencher. Archives of Biochemistry and Biophysics, $274(4), 532-538$.

Donovan, J., Meyer, A., \& Waterhouse, A. (1998). Phenolic composition and antioxidant activity of prunes and prune juice (Prunus domestica). Journal of Agricultural and Food Chemistry, 46(4), 12471252. doi:10.1021/jf970831x

Droge, W., \& Schipper, H. M. (2007). Oxidative stress and aberrant signaling in aging and cognitive decline. Aging Cell, 6(3), 361370. doi:10.1111/j.1474-9726.2007.00294.x

Duvernay, W., Assad, J., Sabliov, C., Lima, M., \& Xu, Z. (2005). Microwave extraction of antioxidant compounds from rice bran. Pharmaceutical Engineering, 25(4), 1-5.

Ewald, C, Fjelkner-Modig, S, Johansson, K, Sjoholm, I, \& Akesson, B. (1999). Effect of processing on major flavonoids in processed onions, green beans, and peas. Food Chemistry, 64 (2), 231-235. doi:10.1016/S03088146(98)00136-8

Fereidoon, S., \& Champaign, I. (1997). Natural antioxidants chemistry health effects and application. pp. 1826-3489. USA: AOCS Press.

Firuzi, O., Fuksa, L., Spadaro, C., Bousova, I., Riccieri, V., Spadaro, A., ... Saso, L. (2006). Oxidative stress parameters in different systemic rheumatic diseases. Journal of Pharmacy and Pharmacology, 58(7), 951-957. doi:10.1211/jpp.58.7.0010
Foo, L., \& Lu, Y. (1999). Isolation and identification of procyanidins in apple pomace. Food Chemistry, 64 (4), 511-518.

Food Safety. (2008). accessed on 23 January 2013. Retrieved from http : / / www . uoguelph.ca/foodsafetynetwork/

Foss, B., Sliwka, H., Partali, V, Cardounel, A., Zweier, J., \& Lockwood, S. (2004). Direct superoxide anion scavenging by a highly water-dispersible carotenoid phospholipid evaluated by electron paramagnetic resonance (EPR) spectroscopy. Bioorganic \&6 Medicinal Chemistry Letters, 14(11), 2807-2812. doi:10.1016/j.bmcl.2004.03.061

Fox, P., \& McSweeney, P. L. (1998). Milk lipids. In Fox, P. F., \& McSweeney, P. L. H. (eds.). Dairy Chemistry and Biochemistry. p.127134. New York: Kluwer Academic/Plenum Publishers..

Frankel, E., \& Meyer, A. (1998). Antioxidants in grapes and grape juices and their potential health effects. Pharmaceutical Biology, 36(S), 14-20. doi:10.1076/phbi.36.6.14. 4561

Frankel, E., Huang, S., Kanner, J, \& German, J. (1994). Interfacial Phenomena in the Evaluation of Antioxidants - Bulk Oils vs Emulsions. Journal of Agricultural and Food Chemistry, 42(5), 1054-1059. doi:10.1021/ jf00041a001

Frankel, E., Waterhouse, A., \& Teissedre, P. (1995). Principal Phenolic Phytochemicals in Selected California Wines and Their Antioxidant Activity in Inhibiting Oxidation of Human Low-Density Lipoproteins. Journal of Agricultural and Food Chemistry, 43(4), 890-894. doi:10.1021/jf00052a008

Garcia-Viguera, C., Zafrilla, P., \& TomasBarberan, F. (1997). Determination of the authenticity of fruit jams by hplc analysis of anthocyanins. Journal of Science Food and Agriculture, 73(2), 207-213.

Geronikaki, A. A., \& Gavalas, A. M. (2006). Antioxidants and inflammatory disease: Synthetic and natural antioxidants with anti-inflammatory activity. Combinatorial Chemistry \& High Throughput Screening, 9(6), 425-442. doi:10.2174/138620706777698481 
Gharby, S., Harhar, H., Guillaume, D., Haddad, A., \& Charrouf, Z. (2012). The Origin of Virgin Argan Oil's High Oxidative Stability Unraveled. Natural Product Communications, 7(5), 621-624.

Gordon, M. (2001). The developments of oxidative rancidity in foods. In J. Pokorny, N. Yanishlieva, M. Gordon (Eds.). Antioxidants in food and practical applications. pp 21-22.United Kingdom: CRC press, Woodhead publishing Ltd.

Gordon, M., \& Kourimska, L. (1995). Effect of Antioxidants on Losses of Tocopherols During Deep-Fat Frying. Food Chemistry, 52(2), 175-177. doi:10.1016/0308-8146(94) P4200-Y

Guchhait, S., Arora, S., \& Rai, T. (1998). Ghee residue- its nutritional value and antioxidant properties. Journal of Food Science 8 Technology, 18(2), 107-148.

Gunstone, F. D., \& Honorary, M. (2004). Chemical properties related to unsaturated centers. In Frank D. Gunstone (eds.). The chemistry of oils and fats. p.164165. United Kingdom: Blackwell pub.CRC Press.

Guo, Z., Jin, Q., Fan, G., Duan, Y., Qin, C, \& Wen, M. (2001). Microwave-assisted extraction of effective constituents from a Chinese herbal medicine Radix puerariae. Analytica Chimica Acta, 436(1), 41-47. doi:10.1016/S0003-2670(01)00900-X

Hakkinen, S., Karenlampi, S., Heinonen, I., Mykkanen, H., \& Torronen, A. (1999). Content of the flavonols quercetin, myricetin, and kaempferol in 25 edible berries. Journal of Agricultural and Food Chemistry, 47(6), 2274-2279. doi:10.1021/jf9811065

Hakkinen, S., Karenlampi, S., Mykkanen, H., \& Torronen, A. (2000). Influence of domestic processing and storage on flavonol contents in berries. Journal of Agricultural and Food Chemistry, 48(7), 2960-2965. doi:10.1021/ jf991274c

Harsh, P., Walker, T., Schweizer, H., \& Vivanco, J. (2002). Root specific elicitation and antimicrobial activity of rosmarinic acid in hairy root culture of ocimum basilicum.
Plant Physiology $\&$ Biochemistry, 40(11), 983-995.

Heinonen, I., Meyer, A., \& Frankel, E. (1998). Antioxidant activity of berry phenolics on human low-density lipoprotein and liposome oxidation. Journal of Agricultural and Food Chemistry, 46(10), 4107-4112. doi:10. 1021/jf980181c

Heinonen, M., Ollilainen, V, Linkola, E., Varo, P., \& Koivistoinen, P. (1989). Carotenoids in Finnish Foods - Vegetables, Fruits, and Berries. Journal of Agricultural and Food Chemistry, 37(3), 655-659. doi:10.1021/ jf00087a017

Hertog, M., Hollman, P., \& Katan, M. (1992). Content of Potentially Anticarcinogenic Flavonoids of 28 Vegetables and 9 Fruits Commonly Consumed in The Netherlands. Journal of Agricultural and Food Chemistry, 40(12), 2379-2383. doi:10.1021 / jf00024a011

Hocman, G. (1981). Biochemistry of Aging and Cancer. International Journal of Biochemistry, 13(6), 659-672. doi:10.1016/0020711X(81)90034-3

Hollman, P., \& Arts, I. (2000). Flavonols, flavones and flavanols - nature, occurrence and dietary burden. Journal of the Science of Food and Agriculture, 80(7), 1081-1093. doi:10 . 1002 / (SICI ) 1097 - 0010(20000515) 80:7〈1081::AID-JSFA566〉3.0.CO;2-G

Hong, N, Yaylayan, V., Raghavan, G., Pare, J., \& Belanger, J. (2001). Microwave-assisted extraction of phenolic compounds from grape seed. Natural Product Letters, 15(3), 197204. doi:10.1080/10575630108041280

Hsieh, R., \& Kinsella, J. (1986). LipoxygenaseCatalyzed Oxidation of N-6 and N-3 Polyunsaturated Fatty-Acids - Relevance to and Activity in Fish Tissue. Journal of Food Science, 51(4), 940-945. doi:10.1111/ j.1365-2621.1986.tb11204.x

Hussein, A, Odumeru, J., Ayanbadejo, T, Faulkner, H, McNab, W., Hager, H, \& Szijarto, L. (2000). Effects of processing and packaging on vitamin $\mathrm{C}$ and beta-carotene content of ready-to-use (RTU) vegetables. Food Research International, 33(2), 131136. doi:10.1016/S0963-9969(00)00027-2 
Ibbotson, A. (2008). Boom in natural antioxidants attracts outside interest. accessed on 23 January 2013. Retrieved from htpp:// www.nutraingredients.com

Iqbal, S, Bhanger, M., \& Anwar, F. (2005). Antioxidant properties and components of some commercially available varieties of rice bran in Pakistan. Food Chemistry, 93(2), 265-272. doi:10.1016/j. foodchem. 2004.09.024

Jadhav, S. J., Nimbalkar, S., Kulkami, A., \& Madhavi, D. (1996). Lipid oxidation in biological and food systems. In Madhavi DL, Deshpande SS, Salunkhe DK. (eds.). Food antioxidants. p 5[U+FFFD]64. New York: Marcel Dekker Inc.

Jayadeep, A., Singh, V., Rao, B. V. S., Srinivas, A., \& Ali, S. Z. (2009). Effect of Physical Processing of Commercial De-oiled Rice Bran on Particle Size Distribution, and Content of Chemical and Bio-functional Components. Food and Bioprocess Technology, 2(1), 57-67. doi:10.1007/s11947-0080094-6

Jayathilakan, K., Sharma, G. K., Radhakrishna, K., \& Bawa, A. S. (2007). Effect of natural antioxidants on the lipid stability of fluidised bed-dried mutton. Food Chemistry, $100(2)$, 662-668. doi:10.1016/j.foodchem. 2005.09 .083

Johnson, I. (2001). Antioxidants and antitumour properties. In: Pokorny J, Yanishlieva N, Gordon M, eds. Antioxidants in food: Practical applications. p.100-123. Cambridge: CRC Press.

Jones, J. (1992). Food additives. in Food safety. St.Paul, MN: Eagon Press.

Kahkonen, M., Hopia, A., \& Heinonen, M. (2001). Berry phenolics and their antioxidant activity. Journal of Agricultural and Food Chemistry, 49(8), 4076-4082. doi:10. 1021/jf010152t

Kalt, W, Forney, C., Martin, A, \& Prior, R. (1999). Antioxidant capacity, vitamin C, phenolics, and anthocyanins after fresh storage of small fruits. Journal of Agricultural and Food Chemistry, 47(11), 46384644. doi:10.1021/jf990266t

Kaufmann, B, \& Christen, P. (2002). Recent extraction techniques for natural products:
Microwave-assisted extraction and pressurised solvent extraction. Phytochemical Analysis, 13(2), 105-113. doi:10.1002/pca. 631

Keceli, T, \& Gordon, M. (2002). Ferric ions reduce the antioxidant activity of the phenolic fraction of virgin olive oil. Journal of Food Science, 67(3), 943-947. doi:10.1111/ j.1365-2621.2002.tb09432.x

Kiss, G., Forgacs, E, Cserhati, T, Mota, T, Morais, H, \& Ramos, A. (2000). Optimisation of the microwave-assisted extraction of pigments from paprika (Capsicum annuum L.) powders. Journal of Chromatography A, 889(1-2), 41-49. 9th Symposium on Handing of Environmental and Biological Samples, OPORTO, PORTUGAL, OCT 10-13, 1999.

Kolak, U., Ozturk, M., Ozgokce, F., \& Ulubelen, A. (2006). Norditerpene alkaloids from Delphinium linearilobum and antioxidant activity. Phytochemistry, 67(19), 2170-2175. doi:10.1016/j.phytochem.2006.06.006

Kumar, P., Chu, C., Krishnaiah, D., \& Bono, A. (2006). High hydrostatic pressure extraction of antioxidants from morinda citrifolia fruit [please insert "prerenderunicode-"unichar-65533"" into preamble] process parameters optimization. Journal of Engineering Science and Technology, $1(1), 41-49$.

Laroze, L. E., Diaz-Reinoso, B., Moure, A., Elvira Zuniga, M., \& Dominguez, H. (2010). Extraction of antioxidants from several berries pressing wastes using conventional and supercritical solvents. European Food Research and Technology, 231 (5), 669-677. doi:10.1007/s00217-0101320-9

Leal, P. F., Maia, N. B., Carmello, Q. A. C., Catharino, R. R., Eberlin, M. N., \& Meireles, M. A. A. (2008). Sweet Basil (Ocimum basilicum) Extracts Obtained by Supercritical Fluid Extraction (SFE): Global Yields, Chemical Composition, Antioxidant Activity, and Estimation of the Cost of Manufacturing. Food and Bioprocess Technology, 1 (4), 326-338. doi:10. 1007 / s11947 - 007 0030- 1 
Lee, H, Chung, B., \& Park, Y. (1991). Concentration of Tocopherols from Soybean Sludge by Supercritical Carbon-Dioxide. Journal of the American Oil Chemists Society, 68(8), 571-573. doi:10.1007/BF02660152

Lee, J., Kim, M., \& Choe, E. (2007). Antioxidant activity of lignan compounds extracted from roasted sesame oil on the oxidation of sunflower oil. Food Science and Biotechnology, 16(6), 981-987.

Lees, D., \& Francis, F. (1972). Effect of Gamma-Radiation on Anthocyanin and Flavonol Pigments in Cranberries (Vaccinium-Macrocarpon Ait). Journal of the American Society for Horticultural Science, 97(1), 128-132.

Lees, G., Wall, K., Beveridge, T., \& Suttill, N. (1995). Localization of condensed tannins in apple fruit peel, pulp, and seeds. Canadian Journal of Botany-Revue Canadienne de Botanique, 73(12), 1897-1904.

Li, X.-X., Han, L.-J., \& Chen, L.-J. (2008a). In vitro antioxidant activity of protein hydrolysates prepared from corn gluten meal. Journal of the Science of Food and Agriculture, 88(9), 1660-1666. doi:10.1002/jsfa. 3264

Li, Y., Jiang, B., Zhang, T., Mu, W., \& Liu, J. (2008b). Antioxidant and free radical-scavenging activities of chickpea protein hydrolysate $(\mathrm{CPH})$. Food Chemistry, 106(2), 444-450. doi:10.1016/ j . foodchem.2007.04.067

Liebler, D., Baker, P., \& Kaysen, K. (1990). Oxidation of Vitamin-E - Evidence for Competing Autoxidation and Peroxyl Radical Trapping Reactions of the Tocopheroxyl Radical. Journal of the American Chemical Society, 112(19), 6995-7000. doi:10.1021/ ja00175a037

Lingnert, H, \& Eriksson, C. (1981). Antioxidative Effect of Maillard Reaction-Products. Progress in Food and Nutrition Science, 5(1-6), 453-466.

Macheix, J., Fleuriet, A., \& Billot, J. (1990). Fruit phenolics. Boca Raton, FL: CRC Press.

Madhavi, D. K., D. L.and Salunkhe. (1995). Antioxidants. In J.A. Maga and Anthony,
T.T.U. (eds.). Food additive toxicology. p 89-174, New York: Marcel Dekker, INC.

Mantovani, G, Maccio, A, Madeddu, C, Mura, L, Gramignano, G, Lusso, M., ... Massa, E. (2003). The impact of different antioxidant agents alone or in combination on reactive oxygen species, antioxidant enzymes and cytokines in a series of advanced cancer patients at different sites: Correlation with disease progression. Free Radical Research, 37(2), 213-223. doi:10.1080/ 1071576031000060616

Markowski, J., \& Plocharski, W. (2006). Determination of phenolic compounds in apples and processed apple products. Journal of Fruits and Ornamental Plant Research, 14(2), 133-141.

Matilla, P., \& Kumpulainen, J. (2002). Determination of free and total phenolic acids in plant derived foods by hplc with diode array detection. Journal of Agriculture and Food Chemistry, 50(13), 3660-3667.

Matilla, P., Suanpa, k., \& Piironea, V. (2000). Functional properties of edible mushrooms. Nutrition, 16, 694-696.

McCarthy, T., Kerry, J., Kerry, J., Lynch, P., \& Buckley, D. (2001). Evaluation of the antioxidant potential of natural food/plant extracts as compared with synthetic antioxidants and vitamin $\mathrm{E}$ in raw and cooked pork patties. Meat Science, 58(1), 45-52.

Meyers, D., Maloley, P., \& Weeks, D. (1996). Safety of antioxidant vitamins. Archives of Internal Medicine, 156(9), 925-935. doi:10. 1001/archinte.156.9.925

Michaeli, A, \& Feitelson, J. (1994). Reactivity of Singlet Oxygen Toward Amino-Acids and Peptides. Photochemistry and Photobiology, 59(3), 284-289. doi:10.1111/j.17511097.1994.tb05035.x

Mikova, K. (2002). A case study: antioxidant preservatives. In D.H. Watson. (ed.) Food chemical safety. vol.2, p 285299.Cambridge: CRC Press, Woodhead Publishing.

Miller, D., Hawthorne, S., Gizir, A., \& Clifford, A. (1998). Solubility of polycyclic aromatic hydrocarbons in subcritical water from 298 $\mathrm{K}$ to $498 \mathrm{~K}$. Journal of Chemical and En- 
Antioxidants, their properties, uses in food products and their legal implications $\mid 101$

gineering Data, 43(6), 1043-1047. doi:10. $1021 /$ je980094g

Miller, N., \& RiceEvans, C. (1997). The relative contributions of ascorbic acid and phenolic antioxidants to the total antioxidant activity of orange and apple fruit juices and blackcurrant drink. Food Chemistry, 60(3), 331-337. doi:10 . 1016 / S0308 - 8146(96 ) 00339-1

Min, D. (2007). Chemistry and application of antioxidants. Unpublished paper presented at 11th World Congress of Food Science and Technology, Ohio.

Min, D., \& Boff, J. (2002). Lipid oxidation of edible oil. In Akoh C.C. \& Min D. B. (eds.). Food lipids. $\left(2^{\text {nd }}\right.$ ed). p 335-364. New York: Marcel Dekker Inc.

Mohammed, A. A.-M. (2002). Antioxidant activity of commonly consumed vegetables in yemen. Malaysian Journal of Nutrition, 8(2), 179-189.

Moure, A, Dominguez, H, \& Parajo, J. (2006). Antioxidant properties of ultrafiltrationrecovered soy protein fractions from industrial effluents and their hydrolysates. Process Biochemistry, 41(2), 447-456. doi:10. 1016/j.procbio.2005.07.014

Mullen, W., Marks, S. C., \& Crozier, A. (2007). Evaluation of phenolic compounds in commercial fruit juices and fruit drinks. Journal of Agricultural and Food Chemistry, 55 (8), 3148-3157. doi:10.1021/jf062970x

Nuchter, M, Ondruschka, B, Hoffmann, J, \& Tied, A. (2004). Microwave-assisted reactions of oxiranes with carbon dioxide in ionic liquids. In Park, SE and Chang, JS and Lee, KW (Ed.), Carbon Dioxide Utilization for Global Sustainability (Vol. 153, 131-136). Studies in Surface Science and Catalysis. 7th International Conference on Carbon Dioxide Utilization, Seoul, SOUTH KOREA, OCT 12-16, 2003.

Pan, M., Jiang, T. S., \& Pan, J. L. (2011). Antioxidant Activities of Rapeseed Protein Hydrolysates. Food and Bioprocess Technology, 4(7), 1144-1152. doi:10 . 1007 / s11947-009-0206-y

Pan, X., Niu, G., \& Liu, H. (2003). Microwaveassisted extraction of tea polyphenols and tea caffeine from green tea leaves. Chemical
Engineering and Processing, 42(2), 129133. doi:10.1016/S0255-2701(02)00037-5

Peckic, B., Kovac, V., Alonso, E., \& Revilla, E. (1998). Study of the extraction of proanthocyanidins from grape seeds. Food Chemistry, 61(1-2), 201-206.

Perino-Issartier, S., e Huma, Z., Abert-Vian, M., \& Chemat, F. (2011). Solvent Free Microwave-Assisted Extraction of Antioxidants from Sea Buckthorn (Hippophae rhamnoides) Food By-Products. Food and Bioprocess Technology, 4(6), 1020-1028. doi:10.1007/s11947-010-0438-x

PFA - Prevention of Food Adulteration. (2008). Pfa seventh amendment rules. The Universal law publishing co. pvt. Ltd. pp 102-103.

Plumb, G., Chambers, S., Lambert, N, Wanigatunga, S, \& Williamson, G. (1997). Influence of fruit and vegetable extracts on lipid peroxidation in microsomes containing specific cytochrome P450s. Food Chemistry, 60(2), 161-164. doi:10.1016/S03088146(95)00256-1

Pokorny, J. (2008). Antioxidants in food preservation. In Rahman (eds.). Handbook of Food Preservation (2nd ed). p 259286.U.S.A.: CRC Press.

Pokorny, J. (2001). Natural antioxidant functionality during food processing. In J. Pokorny, N. Yanishlieva, M. Gordon (eds.). Antioxidants in food, practical applications. p.335-351. Cambridge: CRC Press, Woodhead Publishing Ltd.

Rahimi, R., Nikfar, S., Larijani, B., \& Abdollahi, M. (2005). A review on the role of antioxidants in the management of diabetes and its complications. Biomed. Pharmacother, 59, 365-373.

Raman, G, \& Gaikar, V. (2002). Microwaveassisted extraction of piperine from Piper nigrum. Industrial $\&$ Engineering Chemistry Research, 41(10), 2521-2528. doi:10. 1021/ie010359b

Ramanathan, L, \& DAS, N. (1993). NaturalProducts Inhibit Oxidative Rancidity in Salted Cooked Ground Fish. Journal of Food Science, 58(2), 318-320. doi:10.1111/ j.1365-2621.1993.tb04265.x

Rao, S., \& Kiran, V. (2011). Effect of lycopene in tomato as a natural antioxidant in

IJFS | April 2013 |Volume 2 |pages 81-104 
osteoarthritis- a pilot study. International Journal of Academic Research, 3(2), 10761079.

Reinoso, B., Moure, A., Dominguez, H., \& Parajo, J. (2006). Supercritical $\mathrm{co}_{2}$ extraction and purification of compounds with antioxidant activity. Journal of Agricultural and Food Chemistry, 54(7), 24412469.

Reishe, D. A., D. W. andLillard, \& Eitemmiller, R. R. (2008). Antioxidants in food lipids. In C.C. Akoh \& D.B. Min (eds.) Food Lipids: Chemistry, Nutrition, and Biotechnology, 3rd Ed.. p 409-435.. U.S.A.: CRC Press Inc.

Rekha, M. N., Yadav, A. R., Dharmesh, S., Chauhan, A. S., \& Ramteke, R. S. (2010). Evaluation of Antioxidant Properties of Dry Soup Mix Extracts Containing Dill (Anethum sowa L.) Leaf. Food and Bioprocess Technology, 3(3), 441-449. doi:10. 1007/s11947-008-0123-5

RiceEvans, C., Miller, N., \& Paganga, G. (1996). Structure-antioxidant activity relationships of flavonoids and phenolic acids. Free Radical Biology and Medicine, 20(7), 933-956. doi:10.1016/0891-5849(95)022279

Risch, B, \& Herrmann, K. (1988). Contents of Hydroxycinnamic Acid-Derivatives and Catechins in Pome and Stone Fruit. Zeitschrift Fur Lebensmittel-Untersuchung Und-Forschung, 186(3), 225-230. doi:10 . 1007/BF01043317

Rodrigues, S., \& Pinto, G. (2007). Ultrasound extraction of phenolic compounds from coconut (cocos nucifera) shell powder. Journal of Food Engineering, 80(3), 869-872.

Rostagno, M., Palma, M, \& Barroso, C. (2003). Ultrasound-assisted extraction of soy isoflavones. Journal of Chromatography A, 1012(2), 119-128. $2^{\text {nd }}$ Meeting of the Spanish-Society-ofChromatography-and-Related-Techniques, BARCELONA, SPAIN, NOV 26-29, 2002. doi:10.1016/S0021-9673(03)01184-1

Santos-Buelga, C, \& Scalbert, A. (2000). Proanthocyanidins and tannin-like compounds - nature, occurrence, dietary intake and effects on nutrition and health. Journal of the Science of Food and Agriculture,
80(7), 1094-1117. doi:10.1002/(SICI)10970010(20000515) 80:7 71094::AID- JSFA569〉 3.0.CO;2-1

SaperS, G., Phillips, J., Rudolf, H., \& Divito, A. (1983). Cranberry Quality - Selection Procedures for Breeding Programs. Journal of the American Society for Horticultural Science, 108(2), 241-246.

Sapers, G., Jones, S., \& Maher, G. (1983). Factors Affecting the Recovery of Juice and Anthocyanin From Cranberries. Journal of the American Society for Horticultural Science, 108(2), 246-249.

Schmidt, S., \& Pokorny, J. (2001). Natural antioxidant functionality during food processing. In J. Pokorny, N. Yanishlieva, M. Gordon (Eds.)., Antioxidants in food, practical applications, p 331- 339.Florida: CRC Press, Woodhead Publishing Ltd.

Seabra, I. J., Braga, M. E. M., Batista, M. T. P., \& de Sousa, H. C. (2010). Fractioned High Pressure Extraction of Anthocyanins from Elderberry (Sambucus nigra L.) Pomace. Food and Bioprocess Technology, 3(5), 674683. doi:10.1007/s11947-008-0134-2

Shah, S, Richter, R., \& Kingston, H. (2002). Microwave-assisted organic extraction and evaporation: An integrated approach. $L C$ GC North America, 20(3), 280+.

Shahidi, F., \& Zhong, Y. (2001). Antioxidants: Regulatory Status. In Shahidi, F., A (eds.). Bailey's Industrial Oil and Fat Products. 6th edition (vol. 2), p. 491-513. Michigan: Jon Wiley \&Sons, Inc.

Shantilal, S. P. (1984). Effect of mango seed kernels on oxidative stability of ghee. (Master's thesis, Unpublished Master's thesis submitted to Gujarat Agricultural University, Anand, Gujarat (India)).

Sheabar, F., \& Neeman, I. (1988). Separation and Concentration of Natural Antioxidants from the Rape of Olives. Journal of the American Oil Chemists Society, 65(6), 990-993. doi:10.1007/BF02544526

Siekmeier, R., Steffen, C., \& Maerz, W. (2007). Role of oxidants and antioxidants in atherosclerosis: Results of in vitro and in vivo investigations. Journal of Cardiovascular Pharmacology and Ther- 
apeutics, 12(4), 265-282. doi:10 . 1177/ 1074248407299519

Sorensen, M, Jensen, B., Poulsen, H., Deng, X., Tygstrup, N, Dalhoff, K, \& Loft, S. (2001). Effects of a Brussels sprouts extract on oxidative DNA damage and metabolising enzymes in rat liver. Food and Chemical Toxicology, 39(6), 533-540. doi:10.1016/S02786915(00)00170-8

Spence, J. D. (2006). Nutrition and stroke prevention. Stroke, 37(9), 2430-2435. doi:10. 1161/01.STR.0000236633.40160.ee

St. Angelo, A. J., Vercellotti, J., Jacks, T., \& Legendre, M. (1996). Lipid oxidation in foods. Critical Reviews in Food Science and $\mathrm{Nu}$ trition, 36(3), 175-224.

Stohr, H, \& Herrmann, K. (1975). Occurrence of Derivatives of Hydroxycinnamic Acids, Hydroxybenzoic Acids, and Hydroxycoumarins in Citrus Fruits. Zeitschrift Fur Lebensmittel-Untersuchung UndForschung, 159(5), 305-306. doi:10.1007/ $\mathrm{BF} 01139585$

Thiyam, U, Kuhlmann, A, Stockmann, H, \& Schwarz, K. (2004). Prospects of rapeseed oil by-products with respect to antioxidative potential. Comptes Rendus Chimie, 7(6-7), 611-616. International Symposium on Green Chemistry, Poitiers, FRANCE, MAY 19-22, 2003. doi:10.1016/j.crci.2004. 02.011

Thorat, I. D., Mohapatra, D., Sutar, R. F., Kapdi, S. S., \& Jagtap, D. D. (2012). Mathematical Modeling and Experimental Study on Thin-Layer Vacuum Drying of Ginger (Zingiber Officinale R.) Slices. Food and Bioprocess Technology, 5(4), 1379 1383. doi:10.1007/s11947-010-0429-y

Tomas-Barberan, F., Gil, M., Cremin, P, Waterhouse, A., Hess-Pierce, B, \& Kader, A. (2001). HPLC-DAD-ESIMS analysis of phenolic compounds in nectarines, peaches, and plums. Journal of Agricultural and Food Chemistry, 49(10), 4748-4760. doi:10. 1021/jf0104681

Torres, P., Kunamneni, A., Ballesteros, A., \& Plou, F. J. (2008). Enzymatic modification for ascorbic acid and tocopherol to enhance their stability in food and nutritional appli- cations. The Open Food Science Journal, 2, 1-9.

Trivedi, J. B. (2008). Extraction of antioxigenic principle from oat and their effect on oxidative stability of ghee. (Master's thesis, Unpublished Master's thesis submitted to Gujarat Agricultural University, Anand, Gujarat (India)).

van den Berg, H, Faulks, R, Granado, H., Hirschberg, J, Olmedilla, B, Sandmann, G, ... Stahl, W. (2000). The potential for the improvement of carotenoid levels in foods and the likely systemic effects. Journal of the Science of Food and Agriculture, 80(7), 880-912. doi:10.1002 / (SICI) 1097 0010(20000515)80:7〈880::AID-JSFA646〉3. 3. CO;2- T

Vaya, J., \& Aviram, M. (1999). Nutritional antioxidants: mechanism of action, analyses of activities and medical application. $\mathrm{Nu}$ trition, 49, 1-7.

Verma, S., \& Sahoo, J. (2000). Extension of shelf life of ground chevon during refrigerated storage by using ascorbic acid. Journal of Food Science and Technology-Mysore, $37(6), 565-570$.

Vijaya, J., \& Vidyasagar, S. (2009). Antioxidants and heart disease. In R.R. Watson (ed.). Hand book of Nutrition In the aged, 4th Ed., p 75-91. Tucson: CRC Press.

Viljanen, K., Sunberg, S., Ohshima, T., \& Heinonen, M. (2002). Carotenoids as antioxidants to prevent photooxidation. European Journal of Lipid Science and Technology, 104 (6), 353-359.

Vision, J. A., Jang, J., Yang, J., Dabbagh, Y., Liang, X., \& Sery, M. (1999). Vitamins and especially flavonoids in common beverages are powerful in vitro antioxidants which enrich lower density lipoproteins and increase their oxidative resistance after ex vivo spiking in human plasma. Journal of Agricultural and Food Chemistry, 47(7), 25022504 .

Vollmannova, A., Tomas, J., Urminska, D., Polakova, Z., Melichacova, S., \& Krizova, L. (2009). Content of Bioactive Components in Chosen Cultivars of Cranberries (Vaccinium vitis-idaea L.) Czech Journal of Food Sciences, 27, S248-S251. 6th Chem- 
ical Reactions in Food Conferene 2009, Prague, Czech Republic, May 13-15, 2009.

Wada, L, \& Ou, B. (2002). Antioxidant activity and phenolic content of oregon caneberries. Journal of Agricultural and Food Chemistry, 50(12), 3495-3500. doi:10 . 1021 / jf0114051

Wang, J.-s., Zhao, M.-m., Zhao, Q.-z., \& Jiang, Y.-m. (2007). Antioxidant properties of papain hydrolysates of wheat gluten in different oxidation systems. Food Chemistry, 101(4), 1658-1663. doi:10.1016/j . foodchem.2006.04.024

Wang, Y., Miller, L., \& Addis, P. (1991). Effect of Heat Inactivation of Lipoxygenase On Lipid Oxidation in Lake Herring (Coregonus-Artedii). Journal of the American Oil Chemists Society, 68(10), 752-757. doi:10.1007/BF02662166

Whittern, C., Miller, E., \& Pratt, D. (1984). Cottonseed Flavonoids as Lipid Antioxidants. Journal of the American Oil Chemists Society, 61(6), 1075-1078. doi:10 . 1007/ BF02636224

Wijewickreme, A., \& Kitts, D. (1998). Metal chelating and antioxidant activity of model Maillard reaction products. In Shahidi, F and Ho, CT and vanChuyen, N (Ed.), Process-Induced Chemical Changes in Food (Vol. 434, 245-254). Advances in Experimental Medicine and Biology. Pacifichem 1995 Conference, Honolulu, Hawaii, Dec 17-22, 1995.

Williams, O., Raghavan, V., Orsat, V., \& Dai, J. (2002). Microwave assisted extraction of capsaicinoids from capsicum species. Unpublished paper presented at ASAE Annual International Meeting/ CIGR XVth World Congress. Chicago, IL, USA.

Xie, Z., Huang, J., Xu, X., \& Jin, Z. (2008). Antioxidant activity of peptides isolated from alfalfa leaf protein hydrolysate. Food Chemistry, 111 (2), 370-376. doi:10.1016/j. foodchem.2008.03.078

Yanishlieva-Maslarova, N. (2001). Inhibition oxidation. In J. Pokorny, N. Yanishlieva, M. Gordon (eds.). Antioxidants in food practical applications, p 35-59.Cambridge: CRC press, Woodhead Publishing Ltd.
Zhang, S., Zhu, J., \& Wang, C. (2004). Novel high pressure extraction technology. International Journal of Pharmaceutics, 278(2), 471-474. doi:10.1016/j.ijpharm.2004.02. 029

Zhu, K., Zhou, H., \& Qian, H. (2006). Antioxidant and free radical-scavenging activities of wheat germ protein hydrolysates (WGPH) prepared with alcalase. Process Biochemistry, 41(6), 1296-1302. doi:10 . 1016/j.procbio.2005.12.029 